San Jose State University

SJSU ScholarWorks

Master's Theses

Master's Theses and Graduate Research

1994

\title{
A proposal for the establishment of the first non-governmental environmental society in the kingdom of Saudi Arabia
}

Ahmed AbdAllah Al-Senany

San Jose State University

Follow this and additional works at: https://scholarworks.sjsu.edu/etd_theses

\section{Recommended Citation}

Al-Senany, Ahmed AbdAllah, "A proposal for the establishment of the first non-governmental environmental society in the kingdom of Saudi Arabia" (1994). Master's Theses. 891.

DOI: https://doi.org/10.31979/etd.avjk-tr4m

https://scholarworks.sjsu.edu/etd_theses/891

This Thesis is brought to you for free and open access by the Master's Theses and Graduate Research at SJSU ScholarWorks. It has been accepted for inclusion in Master's Theses by an authorized administrator of SJSU ScholarWorks. For more information, please contact scholarworks@sjsu.edu. 


\section{INTORMATION TO USERS}

This manuscript has been reproduced from the microfilm master. UMI films the text directly from the original of copy submitted. Thus, some thesis and dissertation copies are in typewriter face, while others may be from any type of computer printer.

The guality of this reproduction is dependent upon the quality of the copy submitted. Broken or indistinct print, colored or poor quality illustrations and photographs, print bleedthrough, substandard margins, and improper alignment can adversely affect reproduction

In the unlikely event that the author did not send UMI a complete manuscript and there are missing pages, these will be noted. Also, if unauthorized copyright material had to be removed, a note will indicate the deletion.

Oversize materials (e.g., maps, drawings, charts) are reproduced by sectioning the original, beginning at the upper left-hand corner and contimuing from left to right in equal sections with small overlaps. Each original is also photographed in one exposure and is included in reduced form at the back of the book

Photographs included in the original manuscript have been reproduced xerographically in this copy. Higher quality $6^{\prime \prime} \times 9^{n}$ black and white photographic prints are available for any photographs or illustrations appearing in this copy for an additional charge. Contact UMI directly to order.

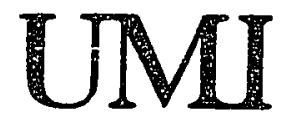

A Bell \& Howell information Company 300 North Zeeb Road. Ann Azbor. Mil 48106-1346 USA $313: 761-4700 \quad 800: 521-0600$ 



\title{
A PROPOSAL FOR THE ESTABLISHMENT \\ OF THE FIRST NON-GOVERNMENTAL ENVIRONMENTAL SOCIETY \\ IN THE KINGDOM OF SAUDI ARABIA
}

\author{
A Thesis \\ Presented to
}

The Office of Graduate Studies

San Jose State University

In Partial Fulfillment

of the Requirements for the Degree

Master of Science

Interdisciplinary Studies

Environmental Administration: Coordination of Environmental Affairs

by

Ahmed AbdAllah Al-Senany

December 1994 
UMI Number: 1361149

Copyright 1994 by

Al-Senany, Ahmed Abdallah

All rights reserved.

UMI Microform Edition 1361149

Copyright 1995, by UMI Company. All rights reserved.

This microform edition is protected against unauthorized copying under Title 17, United States Code.

\section{UMI}

300 North Zeeb Road

Ann Arbor, MI 48103 
(C) 1994

Ahmed AbdAllah Al-Senany

ALL RIGHTS RESERVED 
APPROVED FOR THE OFFICE OF GRADUATE STUDIES

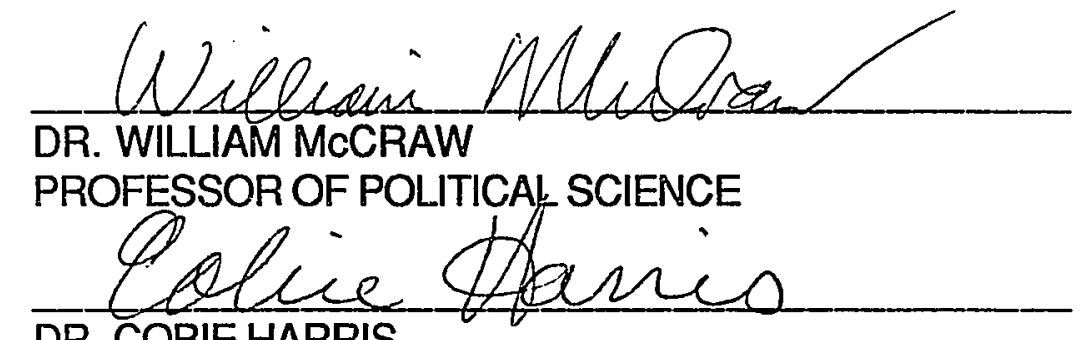

DR. COBIE HARRIS

ASSISTANT PROFESSOR OF POLITICAL SCIENCE

ACTING CHAIR, AFRO-AMERICAN STUDIES

DEPARTMENT

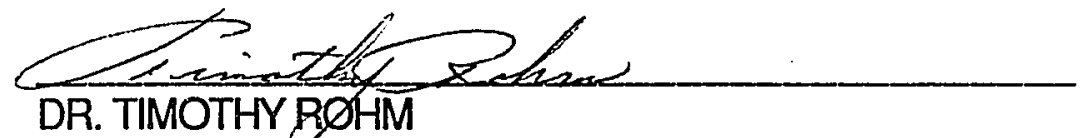

LECTURER IN BIOLOGICAL SCIENCES, ENVIRONMENTAL HEALTH PROGRAM

APPROVED FOR THE UNIVERSITY

In. Lou Lewndown' 


\author{
ABSTRACT \\ A PROPOSAL FOR THE ESTABLISHMENT \\ OF THE FIRST NON-GOVERNMENTAL ENVIRONMENTAL SOCIETY \\ IN THE KINGDOM OF SAUDI ARABIA \\ by Ahmed AbdAllah Al-Senany
}

This thesis constructs a new environmental theory and demonstrates that Islam, the official religion of the Kingdom of Saudi Arabia, offers a holistic view of and applicable principles for the conservation and protection of the planetary environment. It delineates the teachings of Islam concerning the individual's duty and role in the care of the environment. This work contains the first national public opinion survey on environmental affairs in the Kingdom of Saudi Arabia. One significant finding is that strong support exists for citizens' environmental work through environmental societies. It also analyzes current environmental organizations and policies, briefly surveys the state of the environment, and examines models of non-governmental societies in the Kingdom. In its conclusion the thesis recommends the establishment of the first non-governmental environmental society in the Kingdom and provides a proposed charter. 
In the Name of Allah the Merciful, The Compassionate

This work, which fulfills a promise, is dedicated to the memory of my father AbdAllah Hamad Ali Al-Senany (1932-1988), a pioneer, a great poet, and educator who taught me and many others perseverance and love of our country.

It is also dedicated to my son AbdAllah and my daughter Sana, who were born during my struggling years as a graduate student in the United States of America, and to every child of my country, the Kingdom of Saudi Arabia, and to all the children of the world.

This is also dedicated to our dear planet: the Earth. 


\section{ACKNOWLEDGMENTS}

The author wishes to acknowledge with great gratitude and appreciation Professor William McCraw, the thesis committee chairman, who supported this thesis since it was an idea until it was completed and accepted, for his continued personal and academic support and guidance, and the efforts and time he was willing to give beyond the call of duty. Thanks also to Dr. Timothy Rohm, my professor of Environmental Health at San Jose State University, for his assistance to me both as a student in the classroom and during the thesis stage. And to Dr. Cobie Harris, a special kind of man, who believed in me and without hesitation was the first to accept being a member of my thesis committee.

Thanks are also due to Dr. Adnan Daoud, Associate Dean of the College of Social Sciences, and to Dr. Mary Lou Lewandowski, Associate Dean of Graduate Studies and Research, who helped make this thesis and degree become a reality. Finally, thanks to Dr. Alden Voth, retired professor of International Relations, for his continued support and friendship.

In conclusion, a special acknowledgement for their assistance in analyzing the survey questionnaire data is due to the Educational Research Center of King Saud University in Al-Riyadh, the Kingdom of Saudi Arabia. 


\section{TABLE OF CONTENTS}

CHAPTER ONE

CHAPTER TWO

CHAPTER THREE

CHAPTER FOUR

CHAPTER FIVE

CHAPTER SIX

CHAPTER SEVEN
INTRODUCTION

1

THE STATE OF THE ENVIRONMENT 10 IN THE KINGDOM OF SAUDI ARABIA

ISLAMIC CULTURE AND THE ENVIRONMENT

27

CITIZEN PARTICIPATION IN

ENVIRONMENTAL AFFAIRS IN

56

ISLAM: THE CASE OF SAUDI

ARABIA

ENVIRONMENTAL POLICY AND

77

ADMINISTRATION IN THE KINGDOM

OF SAUDI ARABIA

PUBLIC OPINION SURVEY ON

ENVIRONMENTAL AFFAIRS IN

100

THE KINGDOM OF SAUDI ARABIA

CONCLUSIONS AND

120

RECOMMENDATIONS 


\section{LIST OF TABLES}

TABLE ONE

TABLE TWO
PERCENTAGES OF RESPONSE OPINIONS ON THE SEVERITY OF ENVIRONMENTAL PROBLEMS

PERCENTAGES AND AVERAGE SCORES OF OPINIONS ON THE EFFECTIVENESS OF ORGANIZATIONS RESPONSIBLE FOR THE ENVIRONMENT 


\section{CHAPTER 1}

\section{INTRODUCTION}

Islam, the "Supreme Constitution" of the people and the government of Saudi Arabia, provides comprehensive and succinct organizing principles for citizen participation in environmental protection. Despite the fact that the Government of Saudi Arabia had licensed and supported many Saudi non-governmental organizations (local, national and international), it is also a fact that a governmental policy on non-governmentai environmental work has not yet been issued. The establishment of the first non-governmental environmental organization in Saudi Arabia can provide a significant contribution to the welfare of the people and to the government's efforts to protect the environment at the local, national and global levels.

The United Nations Conference on Environment and Development (UNCED), also known as the Earth Summit, held in Rio De Janeiro, Brazil, during June 3-14 1992, was the largest such gathering of world leaders, with more than 100 heads of state or government in attendance. It adopted three major texts. Agenda 21 offered a comprehensive blueprint for global action in all areas of sustainable development. The Rio Declaration on Environment and Development consisted of a series of principles defining the rights and responsibilities of states in this area. Finally, the Conference issued a 
set of principles to guide the sustainable management of forests globally (United Nations, 1992).

Chapter 27 of Agenda 21, entitled "Strengthening the Role of Non-Governmental Organizations: Partners For Sustainable Development," calls on society, governments and international bodies to recognize nongovernmental organizations as partners in the implementation of Agenda 21, and to develop mechanisms to allow them to play their partnership roles responsibly and effectively in the process of promoting environmentally sound and sustainable development. The basis for this action, Agenda 21 stated, is recognition that:

Non-governmental organizations play a vital role in the shaping and implementation of participatory democracy. Their credibility lies in the responsible and constructive role they play in society... The nature of the independent role played by nongovernmental organizations within a society calls for real participation; therefore, independence is a major attribute of non-governmental organizations and is the precondition of real participation. (1992, vol. 3, p. 19)

\section{The Problem}

The largest oil spill in the history of this planet occurred in the Arabian Gulf in January, 1991 during the Kuwait Liberation War. Its subsequent ecological and environmental damage forced the government of the Kingdom of Saudi Arabia to call, for the first time in its history, on Saudi volunteers to help combat the oil spill's ecological effects. The Saudi government at that time also sent urgent appeals for assistance to world governmental and non-governmental environmental organizations. No Saudi non-governmental organization 
participated in this work, however, simply because none existed. During this period, however, the ships of Greenpeace International and other organizations were roaming the Arabian Gulf, conducting studies and research and issuing press releases to the world.

On September 5, 1991 the London-based Arab News newspaper published two contradictory headlines on the same page. The first read "Gulf scientists downplay oil-well fire damage ... .," while the other stated, "Greenpeace says coastline took beating" (Arab News). The first article reported that scientists from the twelve Gulf states were part of a task force set up by the United Nations Environment Prorgram and by the Regional Organization for the Protection of the Marine Environment, which is based in Kuwait. They concluded that ecological damage from the Gulf War would cause less harm to the region than would global warming and the so-called effects of its "greenhouse gases."

The second article was based on a Greenpeace press release issued September 4, 1991, which stated that the Saudi coast had been "damaged beyond repair" (Arab News). The release indicated that a team of Greenpeace scientists working with scientists from two Saudi Arabian organizations--the National Commission for Wildlife Conservation and Development (NCWCD) and the Meteorology and Environmental Protection Administration (MEPA)--had sampled sediments, surveyed the coast and shallow waters and investigated corals, sea grasses and marine life at sites covering 400 kilometers (approximately 250 miles) of this heavily-polluted coastline. The Greenpeace expedition's coordinator, Paul Horsman, concluded that "These shores have been damaged almost beyond recovery and the effects will be felt for years to come." "The authorities need to take the environmental damage seriously," he 
said, and urged "a massive, international clean-up effort involving a large increase in money, resources and personnel." Referring to the 1990 spill in Alaska of the tanker Exxon Valdez, Horsman said that this "much smaller spill . . . attracted 11,000 clean-up personnel and two billion [U.S.] dollars," while the "Gulf spill clean-up is equivalent to a mop and two buckets" (Greenpeace, 1991). Greenpeace's press release also indicated that video footage and photographs of the Saudi oil survey were available from its communications office in London. A further report from the organization was issued in Washington, D.C. early in 1992, stating that the Kuwait War had left a "dangerous" environmental crisis in the region (UNEP/ROWA, 1992). This example of participation by an international activist environmental group in the environmental work of Saudi Arabia might be considered unusual by many observers. However, it demonstrates not only responsiveness and tolerance by the Saudi government, but also the need for the existence of a Saudi nongovernmental environmental organization(s). In fact, several foreign nongovernmental environmental organizations have participated in projects in Saudi Arabia in partnership with governmental environmental organizations, both before and after the Gulf oil spill.

At the same time, many Saudi environmental professionals and officials participate as members or in the leadership of international non-governmental environmental organizations. For example, two top Saudi environmental officials were elected to and served two different terms as deputies to the chairman of the International Union for the Conservation of Nature and Natural Reosurces (IUCN), which is based in Switzerland. 


\section{Scope and Objectives of the Thesis}

The primary objective of this thesis is to evaluate the feasibility of and identify areas of need for non-governmental environmental work in the Kingdom of Saudi Arabia and to outline its foundations from the perspective of the cultural and political systems of the country. The thesis will seek to show how the establishment of the first Saudi non-governmental environmental society can contribute to the government's efforts in protecting the environment, both nationally and internationally, in the light of Agenda 21. A further purpose is to recommend a public policy for citizen participation in environmental protection work and to suggest an applicable model(s) for non-governmental societies. Therefore, a brief survey of environmental conditions in Saudi Arabia will be included, using a report compiled by the Stanford Research Institute of California as a reference. The thesis will describe the environmental machinery and mandates of the Saudi government, as well as its bureaucratic structures, responsibilities and accomplishments. Models of Saudi non-governmental organizations will be analyzed.

\section{Methods and Procedures}

In order to obtain necessary materials and information pertaining to this thesis, the author went to Saudi Arabia from September, 1993 to September, 1994. Research was conducted at many governmental organizations that have environmental functions and environmental reports, data and regulations were requested from them. The applicability of the proposal contained in this thesis 
was discussed with many officials. The King Saud University Library and King AbdalAziz City for Science and Technology furnished additional research material. Videotape recordings of the first symposium on "Cancer Prevention and Early Detection" were obtained from the Directorate General of Health Affairs in Al-Gasseem province. A special questionnaire was prepared by the author and distributed to a selected sample of 350 people to provide the basis for the survey on public opinion on environmental affairs.

Research was also conciucted at professional and philanthropic organizations in Saudi Arabia and letters of inquiry were went to environmental organizations outside Saudi Arabia.

\section{Previous Studies and Investigations}

Published research or information on non-governmental or citizen participation in environmental work does not exist in Saudi Arabia. However, several relevant works were consulted. A primary source of material for this thesis is the Holy Kor'an, and the chronicled sayings and deeds (Sunnah) of the prophet Mohammad.

Dr. Maurice Bucaille, an eminent French surgeon and scholar, published his The Bible, the Qur'an, and Science in France in 1976. It contains the results of his research into the Judeo-Christian Revelations and the Kor'an, which showed that there is no conflict between science and Islam; in fact, they are twin brothers. The book presents an account of many verses in the Kor'an which explain natural phenomena that man was unable to understand until this century. Subjects discussed under this heading include the creation of man, 
astronomy, the creation of the earth, ecology, human reproduction and the animal and vegetable kingdoms. Bucaille stated, "I could not find a single error in the Quran. ... I had not thought it possible for one to find so many statements in a text compiled more than thirteen centuries ago referring to extremely diverse subjects and all of them totally in keeping with modern scientific knowledge" (1979, p. 119).

Al-Mawdudi (1976) wrote a classic entitled Human Rights in Islam, in which he outlined the Islamic political theory: the vicegerency theory. In it he pronounced that, "The state, according to Islam, is nothing more than a combination of men working together as servants of God to carry out his will . . In the working of the state all those [servants] will participate." Al-Mawdudi articulated fifteen basic rights of citizens in an Islamic state; two of these are freedom of association and the right to participate in the affairs of the state.

The fourth major reference is the first and only state of the environment report on Saudi Arabia, issued in 1984. The report concluded that "relatively little quantitative information on environmental conditions in Saudi Arabia is available. What is known indicates that governmental problems exist, as is exemplified by known violations of the recently issued air quality standards" (SRI, 1984, p. ES-12). This work has been used as a benchmark for surveying environmemntal quality during the ten year since it was written by a team of scientists from Stanford Research Institute in Menlo Park, California.

The fifth major source is the book Politics, Administration and Development in Saudi Arabia, edited by Ahmed Dahlan and published in 1990 in the United States. It contains several articles relevant to this thesis. Dr. Bakhashab concluded in his article, "Islamic Law and the Environment: Some Basic 
Principles," that Islamic law urges man to have faith in the almightly, to be thankful for his blessings, to live in harmony with others and nature, and to act righteously for the happiness and well-being of all. This message of Islam is universal and not restricted to any particular nation. Another conclusion following from this is that informing people, and making them aware of the fact that safeguarding their environment is an act of worship, is essential. Indeed, environmental conservation cannot be obtained through the efforts exerted by the state alone. In his article, "Citizen Participation in the Saudi Arabian Local Government," Dahlan defined the meaning and importance of citizen participation. He also outlined the background and process of citizen participation in Saudi Arabia. In the fourth part of his article, which he entitled "The Environment of Citizen Participation," Dahlan included the "Al-shura principle," or mutual consultation, in Section A, concerning the value system, but did not cover it in Section D, which considered the institutional and structural environment. This is probably due to the fact that the Al-Shura Council (Majlis) and Provincial Councils were not established in Saudi Arabia when the book was published in 1990 .

A conference with the theme of "Environment and Development: Complementation, Not Confrontation" was organized by the Riyadh Chamber of Commerce and Industry and the Secretariat General of the Gulf Cooperation Council November 15-17, 1992. It produced a working plan for the environment and development which included sixteen recommendations for all GCC states. The sixth of these encourages "supporting non-governmental, volunteer, and private environmental organizations by allowing them to participate in taking decisions dealing with increased environmental awareness." The "Saudi 
Environmental Awareness Project" was initiated in 1993 as a joint project between the government, represented by the Meteorology and Environmental Protection Administration (MEPA), the Offset Economic Project, a governmentsponsored multinational program, and the private sector. 


\section{CHAPTER 2}

\section{THE STATE OF THE ENVIRONMENT IN THE \\ KINGDOM OF SAUDI ARABIA}

The historical relationship between man and the environment in the Kingdom of Saudi Arabia was one characterized by pastoral nomadism and oasis agriculture, which maintained an efficient balance between the use of natural resources and protection of the environment's long-term ability to sustain life (Shamekh, 1977). The major economic development which began in the 1970 s has, however, radically altered this relationship.

The Saudi Fifth Development Plan stated that:

The Kingdom's rapid economic expansion and unprecedented rate of development and urbanization during the past two decades carried with it certain harmful effects on the country's natural and environmental resources, such as: pollution and health hazards arising from the inadequate handling and treatment of industrial, agricultural, and urban waste and sewage; air pollution in large cities and industrial areas; marine pollution, especially in the vicinity of harbors, industrial complexes and desalination plants; the dangerous rise of the groundwater table under big cities; waterlogging and soil sanitization [salinization]; open sea marine pollution which affects local marine environs; danger to wildlife and a reduction in genetic diversity; and last but not least, the decrease in ground water reserves and a deterioration in its quality. (MOP, 1990, p. 390)

The government's concern for these adverse side effects of economic development was expressed in the establishment of the Meteorology and 
Environmental Protection Administration (MEPA) and the Environmental Protection Coordination Committee in $1401 \mathrm{H}$ (1981) and that of the National Commission for Wildlife Conservation and Development (NCWCD) in $1406 \mathrm{H}$ (1986) and the Ministerial Commission for the Environment in $1410 \mathrm{H}$ (1989). In addition, several other governmental departments have environmental functions, including the Ministries of Interior, Municipalities and Rural Affairs, Health, Planning, Agriculture and Water, Industry and Electricity, Commerce, the Standardization and Metrology organization and others.

Saudi Arabia is located in the southwest portion of the continent of Asia and is approximately 2.25 million square kilometers (approximately 900,000 square miles) in land area. This represents four-fifths of the area of the Arabian Peninsula and is equal to about one-third of that of the United States. The Kingdom is located between longitudes 34 degrees 36 minutes and 56 degrees east, and between latitudes 16 degrees and 32 degrees 12 minutes north (El-Sharif, 1994). Its political boundaries are approximately 6760 kilometers (4225 miles), of which 4430 kilometers (2769 miles) are terrestrial borders. These borders are divided as follows: $740 \mathrm{~km}$ with Jordan, $700 \mathrm{~km}$ with Iraq, $200 \mathrm{~km}$ with the Saudi-Iraqi neutral zone (before division), $210 \mathrm{~km}$ with Kuwait, $540 \mathrm{~km}$ with North Yemen, $700 \mathrm{~km}$ with South Yemen, $700 \mathrm{~km}$ with Oman, $560 \mathrm{~km}$ with the United Arab Emirates and $80 \mathrm{~km}$ with Qatar. Its coastal borders are $1760 \mathrm{~km}$ along the Red Sea and 560 along the Arabian Gulf (ElSharif, 1994). Among its landforms, the western mountain range which parallels the Red Sea is known as Al-Hejaz in the north and the Aseer in the south, where it continues into Yemen. The narrow plain along the coast is known as Tihama. The central plateau, Najd, extends eastwards beyond 
Tuwaiq escarpment to the Al-Dahna desert, which connects the large sand desert of Al-Nafud in the north with the vast desert depression, the Rub Al-Khali, or the empty quarter, in the south. To the east lie the extensive flat coastal plains of the Arabian Gulf.

Geologically, the peninsula forms part of the ancient northeastern section of the African Shelf. The rift of the Red Sea which started fifty million years ago separates the peninsula from present-day Africa (Wittmer \& Buttiker, 1979). The geological structure of the Arabian Peninsula consists of two major units, the Arabian shield and the Arabian shelf. The first of these forms the eastern half of a great circle open to the Red Sea along approximaktely 1800 kilometers of its eastern shores and extends inland for as much as 1000 kilometers to form the great Najd Plateau. The total area of the shield is approximately 610,000 kilometers, or about $27 \%$ of the country's total. This unit contains ore and mineral deposits, such as gold, silver, copper, iron, lead, nickel and zinc. The Arabian shelf is a sequence of sedimentary rocks lying on the northern and eastern flanks of the Arabian shield and extends to the Arabian Gulf. It encompasses almost all the water and petroleum-bearing formations of the Arabian Peninsula (El-Sharif, 1994).

The climate of the Kingdom is dominated by the sub-tropical high pressure ridge which is part of the global tropical circulation known as the Hadley Cell. This cell is characterized by rising air, cloud and rain in the equatorial convergence zone, with the air turning north after its ascent to 14,000 meters. The air sinks as it moves north and reaches the low levels of the atmosphere in the sub-tropical ridge, an extensive high pressure ridge which circles the earth 
in the sub-tropics. On the south side of this ridge the winds blow towards the equatorial conveyance zone to complete the Hadley Cell.

Saudi Arabia lies within the sub-tropical ridge, a region of dry, stable and susiding air throughout deep layers of the troposphere, and is therefore characterized by hot, dry and near-cloudless conditions. In summer the subtropical ridge is weaker than in winter and is displaced further towards the poles. This allows some tropical weather disturbances to occasionally affect the southern part of the Kingdom. The southerly shift of the subtropical ridge in winter allows remnants of the mid-latitude low pressure systems to penetrate the northern part of the Kingdom. Thus the Kingdom's climate is typically dry and hot, with most of the northern stations showing a marked rainfall maximum in winter.

Average cloud cover is usually very small in most parts of the Kingdom. The range of annual sun hours is between 3100 in Gizan and 3500 in Hail. Solar insulation ranges between 200-350 calorie/sq. centimeter/day during January and 400-650 calorie/sq. centimeter/day during July. This, in addition to the climatic zone and several other factors, contributes to the high average diurnal and seasonal temperatures in Saudi Arabia. Average temperatures recorded at 26 weather stations in the Kingdom for the months January and July during 1967-1991 ranged between 35.7 degrees $C$ to 20.8 degrees $C$ ior highest and lowest averages in July, and 25.2 degrees $C$ to 8.3 degrees $C$ for highest and lowest averages in January (El-Sharif, 1994). in the internal regions temperatures could exceed 48 degrees $C$ in summer and go below the freezing point in the winter (MCE, 1992). Saudi Arabia's relative humidity is generally high in the coastal areas, but very low in the interior. Average daily humidity in 
January ranged between $35 \%$ in Khamaseen to $70 \%$ in Gizan, and in July was between $14 \%$, also in Khamaseen, and $68 \%$ in Al wajh. Precipitation is generally less than 200 millimeters annually throughout the country, except in the southwestern highlands, where it ranges from 200 to $500 \mathrm{ml}$ (El-Sharif, 1994).

In 1981 the Ministry of Agriculture and Water produced a soil association map of the Kingdom compiled on a Landsat image base, and in 1985 the Soil Atlas of the Kingdom of Saudi Arabia was produced on a 1:250,000 scale. In it four major soil categories and 37 sub-categories were depicted. Generally, soils of the coastal and inland lowlands or plateaus are sandy to sandy loam in texture, with occasional hardpan which outcrops on the surface. Plateau soils are shallow and stony. There is usually an accumulation of salts, low organic matter, low levels of nitrogen, phosphorus and potassium, and low exchangeable cation capacity. Impenetrable layers are composed mainly of silica, calcium carbonates and metal oxides.

The 1992 national state of the environment report presented to the United Nations Conference on Environment and Development (UNCED) stated that $23.4 \%$ of the total land area, or $52,684,000$ hectares, is arable in terms of fertility and composition. Of these arable lands, $4.2 \%$ are located within good ground water formations.

Although Saudi Arabia is one of the driest countries in the world, its water resources and the fauna and flora associated with them are important elements of the environment. The Kingdom has two major fresh water resources, surface waters and groundwater. 
Its surface waters are primarily constituted by springs and rain waters which form wadis or intermittent streams. The water loss rate in these courses is as high as $70 \%$, however, because of evaporation. Some of these wadis are large and have many tributaries, resembling large rivers geomorphologically. One of the largest valleys in Saudi Arabia is wadi Al-Rummah, which originates in the highland areas near Madinah in the west and pours in Shatt Ai-Arab in the north side of the Arabian Gulf, extending more than 1225 kilometers (EISharif, 1994).

Ground water is found in shallow aliuvial formations and in deep aquifers. The alluvial aquifers are recharged by the infiltration of rainwater which floods the wadis. Infiltration rates have been traditionally enhanced by the building of earth dams and diversion banks in wadis in order to slow the water flow; these are being replaced by modern concrete structures. The deep aquifers contain mostly fossil water which infiltrated the formations thousands of years ago, when the climate was wetter. Carbon 14 dating was used to estimate the age of the AI Saq formation and it was found to be approximately 58,000 years (EISharif, 1994). These formations cover about half of the area of Saudi Arabia and constitute $80 \%$ to $90 \%$ of all water reserves of the country. Hydrological studies indicate that these aquifers may be recharged to some extent by rainwater but, in general, they are being depleted at a fast rate by agriculture .

The composition of the native fauna and flora of Saudi Arabia has been influenced by several geological and climatological evenis. It is an accepted theory that until late in the Tertiary period the Arabian peninsula was connected to the neighboring parts of Africa and Iran. Some 50-60 million years ago gradual formation of the Rift Valley system took place, resulting in the creation of 
the Red Sea in the west and the Arabian Gulf in the east. These events are of basic importance for an understanding of the history of the peninsula's fauna and flora (Wittmer \& Buttiker, 1979). The fauna and flora of Saudi Arabia can be assigned to three of the world's seven biogeographical regions. These are the Palaearctic (northern Hejaz, central and northeastern Saudi Arabia), the Ethiopian (Aseer) and the Oriental (Eastern Province of Saudi Arabia). There is, however, considerable overlapping among these in most parts of the country and, generally speaking, a mosaic pattern is encountered.

Two thousand plant species representing one hundred and fifteen plant families are found in Saudi Arabia (MCE, 1992). The country also contains a variety of animal life. There are approximately 73 species of mammals, four of which are endemic (found only in Saudi Arabia). At least 413 species of birds have been identified, of which 150 breed in Saudi Arabia; of these, ten are endemic. The occurrence of the remaining 263 species points to the importance of Saudi Arabia as a resting and wintering location for migratory birds. Of the 140 reptilian species to be found in the country, seven are amphibians, two are marine turtles, 57 are lizards and 55 are snakes; at least 26 of these species are endemic. In addition, 2000 species of insects and arachnids are found (SRI, 1984; Al-Farraj, 1990). Many of these have only recently been identified. For example, Wittmer \& Buttiker (1979-1987) described approximately 500 previously unknown species.

\section{Environmental Conditions}


Air Quality. Because of its climate, Saudi Arabia is susceptible to several kinds of air pollution. Frequent clear skies and strong solar radiation provide near-perfect conditions for the formation of photochemical air pollutants, such as ozone and other oxidants. At night, these same clear skies allow the surface to lose heat rapidly and the atmosphere to be cooled from beneath, leading to very stable temperature stratifications, low surface wind speeds and low dilution of pollutants emitted near ground level (SRI, 1984).

Photochemical oxidants form from the oxides of nitrogen and organic compounds in the presence of sunlight. Oxides of nitrogen are emitted as a byproduct of any process that involves high-temperature combustion. In Saudi Arabia this includes electricity generation, motor vehicles, desalinization and cement production, among others. The major sources of organic compounds are motor vehicles, petroleum production, refining, transport and the petrochemical industry.

Carbon monoxide, lead aerosol and other motor vehicle pollutants accumulate near their sources. Thus, the highest carbon monoxide and lead aerosol concentrations are found in the heavy traffic areas of major cities. Unleaded gasoline is still not available in Saudi Arabia, but will be in 1995. In addition, a mandatory comprehensive vehicular safety inspection program was started in 1986 which includes an exhaust emissions test. During 1991, some parts of the inspection test became optional. Although the exhaust emissions test is still performed, it is not mandatory that a vehicle pass it in order to be registered.

The sulfur pollutants (sulfur dioxide and sulfates) and inhalable particulates constitute another major category of air pollution. The SRI 1984 report 
identified as the most important source of sulfur dioxide the flaring operations of natural gases and refinery effluents and industries using low-grade fossil fuels. However, the flaring practice was stopped and the gas is being used now by the petrochemical industry in Jubail and Yanbu. Another major source of sulfur pollutants is the large number of trucks on the country's streets and highways which have no controls on emissions and use diesel fuels with high sulfur content. Motor vehicles registered in the Kingdom increased $360 \%$ during $1970-1975$ and $810 \%$ during the period $1975-1985$, and $120 \%$ during $1985-$ 1990. According to statistics from the Ministry of the Interior, the number of registered vehicles in the Kingdom is 3.54 million and is expected to increase to 4.75 million by the year 2000 (MCE, 1992).

Information needs for assessing air quality conditions fall into three categories: climatological data, air quality data, and emission inventories and projections (Al-Senany, 1981). The SRI 1984 report stated that the need for long-term air quality records has been recognized, and the establishment of a national air quality monitoring network is under way by MEPA. However, by 1994, ten years later, this goal had not yet been accomplished. The number of air quality monitoring stations in the industrial city of Jubail alone is more than the monitoring stations in all of the Kingdom.

Water. Fresh water is a scarce resource in Saudi Arabia. Although renewed by rainfall, it is not adequate to support population growth, agriculture and industry on a sustainable basis. Al-Qunaibet (1994) and Al-Welaie (1989) complained that the estimates of petroleum reserves are exactly known, but the same cannot be said about ground water reserves. 
The Ministry of Agriculture introduced a subsidy program in 1978 to encourage wheat production. This policy had increased the production of wheat from 5000 tons in 1978 to 4.5 million tons in 1993, which is about four times the local wheat consumption (Al-Qunaibet, 1994). The World Resources Report 1990-91 informed that Saudi Arabia used about 20,520 million cubic meters of water in 1988. Agriculture consumed about $90 \%$ of the total, or 18,633 million cubic meters, with wheat accounting for about $35 \%$ of agricultural water use. Roughly $90 \%$ of water use is from nonrenewable ground water sources; renewable ground water, surface water and desalinated water make up the balance. The report stated that, according to a confidential U.S. government agency report obtained by the Middle East Economic Digest, at the current rate of depeletion, nonrenewable fossil ground water will be exhausted by 2007 . However, the Saudi government's recent cancellation of the wheat subsidy program is expected to curtail significantly water use by agriculture.

Water Quality. Ground water used for domestic purposes is drawn from wells in rural regions. Urban centers draw on fossil water and desalinated sea water. The water resource is being degraded in some places by a number of human activities, including urban growth, agriculture, overdraft and solid waste disposal. In certain areas, the industrial sector is growing faster than wastewater treatment facilities and is disposing of untreated wastewater in ways that can contaminate, and may already have contaminated, important ground water aquifers with toxic materials (SRI, 1984, MOP, 1990, \& MCE, 1992). The extent of the contamination of these aquifers is unknown because water quality monitoring is not sufficiently extensive and does not include determination of organic contamination (SRI, 1984). MEPA has drafted a revision of water 
quality standards which include 46 toxic organic pesticides and sets maximum allowable concentrations for drinking ("Class A" waters for drinking, "Class B" waters for fishing and "Class C" waters for irrigation) (MCE, 1992).

During 1987 the author collected water samples from the city of Unayzah (which has approximately 100,000 inhabitants) for analysis. The results showed that the samples were contaminated both chemically and biologically and unfit for human consumption.

An extensive survey of industrial and sanitary wastewater treatment and solid waste management practices is needed to determine if important aquifers are or could be damaged by these practices. A comprehensive monitoring program is required to determine current water quality, with special attention devoted to agricultural and industrial organic chemicals.

Solid waste. In Saudi Arabia, open dumping and burning on unused land is the usual way to dispose of solid waste (SRI, 1984).

A major study on solid waste management in Saudi Arabia was conducted in the late 1980s by the Ministry of Municipal and Rural Affairs (MOMRA). The study investigated various aspects of the management and handling of solid waste: categories, handling, recycling, appropriate disposal, site design and monitoring, etc. The study laid the foundation for a waste management strategy for the Kingdom to be implemented by MOMRA (MCE, 1992).

In general, very little information is available on the generation and disposition of solid wastes, toxic substances and hazardous materials. Very broad investigations of these questions are required to determine what management actions are necessary. The consequences of poor managment would extend beyond the unsightliness of open dumps and resource 
conservation issues to include health-threatening exposures to toxic substances and hazardous materials.

Soil. One of the major problems concerning soil in Saudi Arabia is desertification due to overgrazing by animals and overcutting of wood plants. Another real problem is the deterioration of agricultural lands due to salinization; concentration on farming crops, such as wheat and barley, that are stressing to the soil; and overuse of synthetic fertilizers. This is in addition to the excessive use of pesticides and the lack of biological pest control programs. During the decade $1980 \cdot 89$, the average kilogram application of fertilizers per hectare has increased steadily from an average of $259 \mathrm{~kg}$ per hectare of seasonally cropped land to nearly double that figure (MCE, 1992)

Marine Environment. Saudi Arabia has extensive coastline on the Red Sea and the Arabian Gulf. Because of low exchange rates with neighboring bodies of water, they have only limited ability to rid themselves of pollution. Adverse environmental impacts on the Red Sea and the Arabian Gulf are generally associated with oil-related pollution, sewage, dredge and landfill operations, thermal and industrial effluents, and bioaccumlation of hazardous materials in organisms used for food.

Oil related pollution with its associated tarballs and slicks is the most visible problem, particularly in the Gulf. Despite the United Nations Environment Program (UNEP) designation of the Red Sea and Arabian Gulf as sensitive areas, oil is entering the marine environment from ballast discharges and spills during ship transfers and oil well operations. Two of the largest oil spills in history occurred in the Arabian Gulf in 1983 during the Iran-Iraq war, and in 1991 during the Kuwait Liberation War. The amount of oil spilled was 1.8 
million barrels in the first and 5-6 millions in the second (MCE, 1992). Dispersants are used to treat oil spills in the gulf, but dispersant/oil mixtures are generally more toxic than the oil alone.

Continued entry of significant quantities of hydrocarbons into the marine environment is reducing the overall productivity of the affected area. One sign of this has appeared in decreases in commercial fishing activity and shrimp catching. The al-Riyadh newspaper published a press release from the Deputy Minister of Agriculture for Fish Resources stating that, due to the Gulf crisis, the shrimp catch had been reduced fifty per cent compared to its level three years earlier (1994, June 21). Furthermore, the accumulation of hydrocarbons in these organisms makes them unfit for human consumption.

The flow of untreated or partially treated sewage into the Red Sea and the Arabian Gulf has the potential to cause adverse environmental impacts. This problem is largely the result of the inability to build treatment plants and sewage systems at the same pace that occurs in industrial and urban development. Nutrients associated with sewage can alter the ecological balance in favor of nuisance species (e.g, algae) at the expense of corals. In addition, the biological oxygen demand (BOD) associated with organisms feeding on the nutrients can lower oxygen levels in receiving waters. Sewage contaminants such as heavy metals from industrial sources can cause toxic effects or accumulate in sediments and the food chain. Adverse human health effects may also be created by exposure to disease organisms present in sewage and the ingenstion of contaminated fish and shellfish.

Other effluents from industrial processes also enter the marine environment as hot brines from desalination plants, hot water from power plants and 
industrial cooling systems, and water used in industrial processes. Monitoring programs should be implemented to characterize the effluents and their impacts, as well as to determine whether water quality standards are being violated. In addition, because these standards are based largely on data obtained from studies on temperate species, the degree of protection afforded by the standards should be verified with bioassays on native species under local environmental conditions (SRI, 1984).

The potential for accumulation of contaminants in the food chain (i.e., bioaccumulation) is very real. In a preliminary study, mercury levels in the muscle tissue of some fish and shrimp species in the Red Sea were found to range between 0.4 and $0.7 \mathrm{mg} / \mathrm{kg}$. These values approximate or exceed the U.S. mercury standard of $0.5 \mathrm{mg} / \mathrm{kg}$ above which no fish can be sold for human consumption (SRI, 1984).

Biodiversity. Environmental deterioration brought about by natural causes and calamities, such as the spread of epidemic diseases and periodic prolonged droughts, together with overgrazing of pastures and such human activities as hunting with arms, combined to cause the extinction of some wildlife species (MCE, 1992).

Some birds, such as the Houbara bustard and the Arabian bustard, are endangered species. Also, stocks of the Nubian ibex, Dorcas gazelle (Afri) and sand gazelle have approached a very critical level. A number of carnivorous species have disappeared from the country, including the Asiatic lion (Pathera leo) and the Asiatic cheetah (Acinonyx jubatus venaticus) (MCE, 1992).

The national Data Book of Endangered Animals of the Kingdom of Saudi Arabia: Mammals and Birds, MEPA publication No. 2 (1984), lists 22 mammals 
and 11 birds as endangered, although at least four of the mammals are now extinct in the Kingdom and current MEPA estimates place the number of endangered species much higher (MCE, 1992). No publication on endangered plants yet exists, although a MEPA conservative estimate is that at least 50 species are endangered. While this is not a large number, it represents a significant percentage of the present flora (MCE, 1992).

Chemical Safety. During 1984, the World Health Organization called on member countries to join the International Program for Chemical Safety (IPCS). The Ministry of Health in Saudi Arabia called concerned governmental organizations to a meeting to discuss this issue. The ad hoc meeting delegated to MEPA the task of establishing a National Chemical Safety Program which includes a National Register for chemicals such as pesticides, etc.. MEPA drafted the Program document. However, it has not been established yet. A MEPA official stated that this is due to the fact that the Ministry of Finance and National Economy has not allocated the required financial resources. This, however, should not have prevented MEPA from establishing this program and the register, making use of the available financial and human resources.

Pesticides pose a special problem in Saudi Arabia at this time due to the lack of an effective registration and monitoring program. The 1984 SRI state of the environment Report stated that "pesticides are used extensively in agriculture and for local control, but no monitoring is carried out to determine if they are being applied correctly or if workers are handling them properly. Consequently, some form of registration and monitoring program should be implemented to insure that these potentially hazardous materials are applied properly and safely" (P. ES-12). 
Professor Salah Soliman (1992) reported that Saudi Arabia has one of the highest rates of per capita pesticide use (about two kilograms per year), and also per agricultural hectare (about 15 kilograms per year) in the world. During 1976 the Kingdom imported 4999 tons of pesticides which were mostly used for sanitation purposes. Although non-agricultural use remained about the same during 1990, the imported pesticides were 20 thousand tons. He acded that, despite this, the rate and magnitude of the spread of agricultural infestations is also increasing. Soliman lists several reasons for this problem, and among these is the absence of a specialized body to guide farmers on how to choose types of pesticide and on application rates and timing. This is also attributable to not recognizing the fact that pesticide application is but one tool of many which can be used in an Integrated Pest Management (IPM) program.

Soliman argues that the increase in statistics of some chronic and acute health problems in Saudi Arabia, such as hypertension, abortions, food poisoning, neurological disorders, and esophagus and colon cancers, correlates with and is in many cases a result of the increase in the exposure to pesticides in food and the environment (1992). He cited Amer (1985), who reported abnormal clustering of esophageal cancer patients at the Al-Gasseem region of Saudi Arabia, which is the main agricultural center. When compared to population density, the highest prevalence of esophageal cancer was noted in Al-Gasseem, compared to other areas in the Kingdom. The number of referrals from this region to King Faisal Specialist Hospital (KFSH) during 1983 was $159 \%$ more than that in 1980; the increase in pesticides imported over the same period was found to have increased by $171 \%$. Also, the head of the Oncology Department at KFSH reported that a comparison of all cancer 
referrals in the periods 1977-1981 and 1987-1991 revealed an increase in leukemia from $5.1 \%$ to $8.4 \%$ and in breast cancer from $6.5 \%$ to $9 \%$. At the same time, statistics of children's cancers showed that $66 \%$ were leukemia and lymphatic blood carcinoma (Al-Motairy, 1994).

The Kuwait Liberation War and the Environment. The Arabian Gulf had been subjected to an unprecedented assault: five to six million barrels of oil were spilled into the Gulf waters in January 1991, and 616 oil wells were fired in Kuwait, burning an estimated two to six million barrels a day. Between two and four million barrels of the spilied oil reached Saudi Arabian waters. The particulates and gaseous emissions from the fires spread over vast regions, severely affecting all of Northeast Saudi Arabia (MCE, 1992).

The most obvious wildlife mortality was among seabirds. The NCWCD operated a volunteer bird rescue center staffed by both Saudis and non-Saudis. More than 1200 polluted birds were rescued. 


\section{CHAPTER THREE}

\section{ISLAMIC CULTURE AND THE ENVIRONMENT}

Protection of the environment depends on the enforcement of appropriate legislation, and when legislation emanates from a nation's creed and represents its cultural heritage it becomes more effective and useful. Dr. Abdal Bar Al-Gain, President of the Meteorology and Environmental Protection Administration of Saudi Arabia and Vice President of IUCN, asserted that:

This strong relationship between the effectiveness of legislation and the strength of its cultural roots appears to me to be all the more necessary when dealing with environmental issues, especially in Islamic societies. For Islam presents a way of life that encompasses an overall view of the universe, life, man and the interrelationships existing between them and also combines conviction, belief, legislation and enforcement of this legislation. (MEPA, 1983, p. 9)

Islam is the "constitutional" religion of the government and people of the Kingdom of Saudi Arabia, as stated in the "Basic Government Policy" which was issued on 27/8/1412 $\mathrm{H}$ by Royal Decree A/90 from King Fahd bin Abdal-Aziz AlSaud. Item One of this policy states the following: the Kingdom of Saudi Arabia is an Arab Islamic state with full sovereignty, its religion is Islam, its constitution is the Book of Allah (the Koran) and the Sunnah (Words and Deeds) of his messenger (Mohammad), its language is Arabic, and its capital is Al-Riyadh 
city. Item Seven states that the government of the Kingdom of Saudi Arabia obtains its authority from the Holy Book of Allah and the Sunnah of his messenger, and these texts are supreme over this policy and all government policies. Item Forty-Eight states that the courts shall apply Islamic jurisprudence (in cases presented to them) in accordance with the Holy Book and the Sunnah. This evidently means that there is no separation between religion and state in the Kingdom of Saudi Arabia and that Islamic doctrines prevail in governmental affairs at the executive, judicial and administrative levels.

The Kingdom is the birthplace of Islam. The cities of Mecca and Al-Madinah, which house Islam's holiest shrines and are visited by millions of Muslims every year, are located within the Kingdom. It is imperative that the government responsible for the two holy cities declares Islam to be the law of the land. The Holy Kor'an states: "And whoever seeks a religion other than Islam, it will never be accepted of him" (3: 85).

Ahmed Dahlan compared the Saudi government with the ideal form of government in Islam. He then analyzed in depth its Islamic constitution to convince readers that the Saudi monarchy is a "constitutional monarchy" and not an absolute one. Saudi Arabia, Dahlan explains, has an Islamic form of government with power divided between the leader, the Council of Ministers, the Majlis Al-Shura (Consultative Council) and the judicial/legal system. The Shariah (Islamic law), derived from the Kor'an and Sunnah, forms the basis of the Saudi constitution. The constitution, which is under the strict inspection of the body of Islamic scholars, limits and divides the king's power, the power of his Council of Ministers and the power of his governors and the heads of public 
institutions. All laws conform with the constitution, and royal decrees are announced when new political procedures are initiated (Dahlan, 1984).

\section{Islamic Culture}

Culture was defined by Edward B. Taylor as "that complex whole which includes knowledge, belief, art, morals, law, customs and any other capabilities and habits acquired by man as a member of society" (Friedl, 1976, p. 41). Culture can also be defined as the total way of life of a people. Therefore, the content of each culture includes systems of belief (ideology), social institutions (organizations), industrial skills and tools (technology) and material possessions.

Islam means the submission or surrender of one's will to the only true God worthy of worship, "Allah," and anyone who does so is considered a "Muslim." This word also implies "peace," which is the natural consequence of total submission to the will of Allah. Hence, Islam was not a new religion brought by the prophet Mohammad in Arabia in the seventh century, but only the true religion of Allah re-expressed in its final form.

Islam is the religion which was given to Adam, the first man and the first prophet of Allah, and it was the religion of all the prophets sent by Allah to mankind. The name of Allah's religion, Islam, was not decided upon by later generations of man. It was chosen by Allah Himself and is clearly mentioned in His final revelation to man. In the final Book of Divine Revelation, the Kor'an, Allah states the following: "This day, I have perfected your religion for you, 
completed My favor upon you, and have chosen for you Islam as your religion" (5:3).

The prophet Mohammad (Peace be upon him) said that islam consists of five pillars: affirmation of the faith (shahadah), witnessing that there is no Divinity but Allah and that Mohammad is the messenger of Allah; the five daily prayers (al-salat), which Muslims perform facing Makkah (Mecca); fasting (al-sawm) from dawn to sunset during the month of Ramadhan; making the pilgrimage (alhajj) to the holy shrines of Mecca at least once in a lifetime if one's financial and physical condition permit it; and paying a $2.5 \%$ tax (al-zakat) on one's savings, which is given to the needy of the community. Muslims are also commanded to exhort others to peform good acts and to abstain from evil. Ethics lies at the heart of Islamic teachings and all men and women are expected to act ethically towards each other at all times. As the prophet (Pbuh) has said, "None of you is a believer until he likes for his brother what he likes for himself."

\section{The Theory of Environmental Protection in Islam}

Islamic environmental protection theory is based on three main principles: The Oneness of The Creator, the unity and balance of all Creation, and mankind's responsibility as a steward or vicegerent of Allah on the earth-indeed, in the universe.

The Oneness of the Creater. Allah (God) is the only Sovereign, Creator, Sustainer and Owner of the universe, which was created for a purpose. This belief in the oneness of Allah is termed touheed. 
Many languages have one or more terms that are used in reference to God, and sometimes to lesser deities. This is not the case with Allah; Allah is the personal name of the one true God. Nothing else can be called Allah. The term has no plural or gender, which shows its uniqueness when compared with the English word God, which can be made plural (gods) or feminine (goddess). It is interesting in this regard to notice that Allah is the personal name of God in Aramaic, the language of Jesus and a sister language of Arabic.

Attempts were made by some scholars to explain the origins of monotheism among the desert dwellers of the Middle East by environmental factors. Jordan and Rowntree (1986) argued that:

The three major monotheistic faiths (Christianity, Islam, and Judaism) all have their roots among the ciesert dweliers of the Middle East . . . Such desert-dwelling peoples 'receive from the immense monotony of their environment the impression of unity' ... the unobstructed view of the stars and planets provided by the clear desert skies allowed the herders to see that the heavenly bodies moved across the sky in an orderly, repeated progression. This revelation supposedly suggested to the desert stargazers that a single guiding hand was responsible for the orderly system. Semple, in the classic style of environmental determinism, concluded that desert dwellers 'gravitate inevitably into monotheism. (p. 186)

This inference, however, defies history, which records that Mohammad (Pbuh) spent the last twenty-three years of his life calling worshipers of idols and stars to the worship of the one and only God, Allah. In the Kor'an we are told that: "Indeed Allah conferred a great favor on the believers when He sent among them a Messenger [Mohammad] from among themselves, reciting unto them His Verses, and purifying them and instructing them [in] the Book \{Kor'an\} and alHikmah [the wisdom and the Sunnah of the Prophet], while before that they had been in manifest error" (3: 164). 
Jordan and Rowntree then asserted that "some cultural geographers feel that we should look at the social structure of nomadic herding people for answers. . It is possible that the all-powerful male deity of Middle Eastern monotheism is simply a theological reflection of the all-powerful, secular male chieftan" (p. 186). Not so, says the Kor'an. Sura 112, which is considered the essence of the unity--or the motto--of monotheism, states: "1) Say (O Mohammad): He is Allah (the) One, 2) The Everlasting refuge, 3) Who has not begotten, nor has been begotten, 4) And equal to Him is not anyone."

To a Muslim Allah is the Almighty, Creator and Sustainer of the universe who is similar to nothing and nothing is comparable to Him. the Kor'an states:

22) He is Allah, there is no God but He. He is the Knower of the unseen and the visible. He is the All-Milercifui, the AilCompassionate. 23) $\mathrm{He}$ is Allah; there is no God but He. $\mathrm{He}$ is the King, the Holy One, the Source of Peace, the Keeper of Faith, the Guardian, the Almighty, the Subduer, the Sublime. Glory be to Allah above that they associate with Him! 24) He is Allah, the Creator, the Inventor of all things, the Bestower of Forms. To Him belong the Names most Beautiful. All that is in the heavens and the earth glorify Him; and He is the Almighty, the All-Wise. (59: 22-24)

255) Allah! There is no God but He, the Ever-living, the Sustainer and protector of all things. Slumber seizes Him not, neither sleep; to Him belongs all that is in the heavens and the earth. Who is he that can intercede with Him except with His permission? He knows what lies before them and what is after them, and they comprehend not anything of His knowledge except that which He wills. His Seat extends over the heavens and the earth; the preserving of them oppresses Him not; He is the All-High, the AllGlorious. (2: 255)

The Creation of the Heavens and the Earth. The Holy Kor'an, unlike the Old Testament, does not give a unified description of the Creation. As Bucaille has stated, "Instead of a continuous narration, there are passages scattered all over 
the Book which deal with certain aspects of the Creation and provide information on the successive events marking its development with varying degrees of detail" (1979, p. 133).

The Six Periods of Creation. As in the Bible, the Kor'an informs about six days of Creation. The Arabic word yaum, used in the Kor'anic verses, means a period of time, in addition to denoting a day. Strangely, most translations of the Kor'an read yaum to mean day, although the Kor'an quantified yaum to be one thousand years in one verse and fifty thousand years in another. Sura 32, verse 5, states: "... In a period of time [yaum] whereof the measure is a thousand years of your reckoning."

The Divine Creation in six periods is precisely what the preceding verse is stating: "Allah it is He who has created the heavens and the earth, and all that is between them in six periods (ayyam, the plural of yaum) (32: 4). Ibn Kathir (1993), who wrote one of the well-known books on the Koran, explained that there has been a difference of opinion among Islamic scholars concerning the word "ayyam" and noted that Mujahid and Ahmed Bin Hanbal, two well-known Islamic scholars, interpret yaum to mean one thousand years. It is therefore possible to conclude that the Kor'an informs us that the Creation of the universe occurred in six long, indefinite periods of time. Sura 41 , verses 9 to 12 , of the Kor'an states:

Say (O Mohammad), 'Do you verily disbelieve in Him Who created the earth in two periods and ascribe equals to Him? That is the Lord of the worlds; and He set in the (earth) mountains standing firm above it, and He blessed it, and measured therein its sustenance in four equal periods, for all those who ask; then He rose towards the heavens when it was smoke, and said to it and to the earth: "Come both of you, willingly or unwillingly." They said: we come in willing obedience: then He ordained them seven heavens 
in two periods, and He assigned to each heaven its mandate by Revelation. And We adorned the lower heaven with luminaries and protection. Such is the Decree of the All-Mighty, the All-Knower.

The Creation of the earth and heavens in six periods was also reiterated in the following locations in the Kor'an: Sura 7, verse 54; Sura 10, verse 3; Sura 11, verse 7; Sura 25, verse 59; Sura 50, verse 38; Sura 57, verse 4.

Therefore, mankind must protect the environment because it is Allah's Creation. The creation of the earth is a sign of His power, glory, wisdom, mercy and other attributes and therefore serves to let man know and understand his Creator. Environmental protection theory can be based on this (illah) effective cause, according to Islamic jurisprudence (Usul al-figh). But it is not possible to base protection of the environment on man's need for its services, since these are but a reflection of its underlying value and purpose (hikmah). To assume that environmental benefits to man are the sole basis for its protection may lead to its misuse and destruction, thereby impairing those same environmental benefits (Samarrai, M.I., n.d.). Another reason for protecting man's environment is that the whole of Creation, animate and inanimate, worships, glorifies and praises Allah. Mankind might not be able to comprehend how the creatures worship and praise Allah, but this does not mean that they do not do so:

The seven heavens and the earth and all that is therein praise Him, and there is not a thing but glorifies His praise; but ye understand not their glorification ..." (Kor'an, 17:44)

In fact, all elements of the environment have language and feelings:

We subjected the mountains and the birds to glorify our praises along with David. (Kor'an, 21: 79)

And the heavens and the earth wept not for them, nor were they given a respite. (Kor'an, 44: 29) 
Ibn-Jarir Al-Tabari narrated: "Ibn Abbas said: 'When a believer dies, the place of earth on which he (or she) used to prostrate in his (or her) prayer, and the gate in the heaven through which his (or her) good deeds used to ascend, weep for him (or her), while they do not weep for the disbeliever" (Al-Tabari, 1953).

Unity and Balance in the Universe. The unity and balance of the universe is the comprehensive theory of Islam. Islam does not tackle life's problems in fragments, for it does not set up an independent principle to solve each individual problem. It makes from its comprehensive theory an axis around which all other issues revolve. Thus, all the different issues are linked, tightly or loosely, to the axis, and the whole complex forms a unified religious outlook (Qutb, 1977).

Islam reveals the unity and balance in the universe, a unity which comprises all elements from a single particle to the most advanced species. It is the unity of all existence, animate and inanimate. All activities in the cosmos are included and integrated in this unity, whether they concern the rotation of planets or the working of human minds. Islam finds unity in the planets following their eternal law as well as in souls responding to their natural inclinations to acquire knowledge and implement justice. There is unity among all living beings, all species, all generations--in everything encompassed by existence (Qutb, 1977).

According to Isiam, Allah created the earth, the heavens and all between them, in harmony, to manifest the unity of the Divine Principle. Allah set up a balance of Divine justice that encompasses human and natural aspects. Mankind should not violate the balance of nature; this touches upon 
environmental pollution (additions to the ecosystem that make it unbalanced), resource depletion or species extinction (reductions in the ecosystem that make it unbalanced).

The Kor'an says, in Sura 55, Al Rahman, verses 1-8:

1) (Allah) Most Gracious!

2) Has taught (you mankind) the Kor'an

3) He created man

4) He taught him eloquent speech

5) The sun and the moon follow courses (exactly) calculated

6) And the herbs (or stars) and trees both prostrate

7) And the heavens has He raised high, and He has set up the balance.

8) In order that ye may not transgress (due) balance.

This balance ranges from the central laws of the universe to the practices of daily life. Allah gave to each created thing its form, and the guidance to form a unity within the ecosystem. Thus, this balance holds the universe in a complex harmony. As stated in the Kor'an, Sura 20, verse 50:

50) [Moses] said: 'Our Lord is He who gave to each thing its form and nature, and then gave it guidance.'

And Sura 87, verses 1-4:

1) Glorify the name of thy Guardian Lord Most High

2) Who hath created, and further, given order and proportion;

3) Who hath measured. And granted guidance;

4) And Who bringeth out the (green and luscious) pasture.

Everything Allah created in this universe was created in due proportion and measure, both quantitatively and qualitiatively. Allah says in the Holy Kor'an, "Verily, we have created all things with 'Gadar' (Divine pre-ordainments of all things before their creation, as written in the Book of Decrees)" (54:49). And 
says, "... and everything to Him is measured" (13:8). And says, "... and produced therein all kinds of things in due balancen (15:19).

Dr. AbdalMuhsin Saleh, chairman of the Environmental Health Institute at Alexandria University, Egypt, published a book entitled All Kinds of Things in Due Balance, which is devoted to the scientific explanation of the last Kor'anic verse. He began with an explanation of the Divine balance and equilibrium in atoms and molecules. Then he designated chapters on the balance in soil, air, water and the human body, continuing on to the balance at the level of communities and, finally, the balance at the planetary and cosmic levels. Dr. Saleh (1984) concluded that the modern sciences teach to the human mind the craftsmanship, coordination, interdependence and beauty of this universe, and subsequently lead us to a genuine belief in the Creator. This conciusion was explained in the Holy Kor'an in verse 28 of Sura 35: ". . Those who fear Allah (most) among His slaves, are those who have knowledge."

The Almighty Allah contended in the Holy Kor'an that: "He to Whom belongs the dominion of the heavens and the earth, and Who has begotten no son and for Whom there is no partner in the dominion. He has created everything, and has measured it exactly according to its due measurements" (25:2). "And there is not a thing, but with Us are the stores thereof; and We send it not down except in a known measure" (15:21). Further, "And with Him are the keys of the Ghaib (all that is hidden), none knows them but He. And He knows whatever there is on the earth and on the sea; not a leaf falls, but He knows it. There is not a grain in the darkness of the earth, nor anything wet or dry, but is written in a Clear Record" (6:59). 
Therefore, according to the Koran, Allah knows and predetermines the fall of every leaf, which was created by Gadar (pre-ordainment) in due balance, to maintain a larger balance. If the leaves of trees did not fall at that time of year when days are shorter and the activities of all life are reduced, the world would burn due to the excess amount of oxygen in the air. Similarly, if tree leaves do not grow again, then surely all life on earth would die out of suffocation, since those leaves are the global oxygen factories.

Man is told that it is his duty to maintain this unity and balance, to make rational use of everything in the universe and to meditate, contemplate and consider its great work and design by the Lord. Allah says: "And the heavens He has raised high, and He has set up the balance; in order that you may not transgress [due] balance" (Korian, 55: 7-8).

Also: "Do not mischief on the earth, after it hath been set in order" (Kor'an, 7: 56).

Also: "... He (Allah) keeps count of all things (i.e., He knows the exact number of every thing)" (Kor'an, 72: 28).

Also: "... And not an atom's (or small ant's) weight in the earth or the heavens escapeth your Lord, nor what is less or greater than that, but is (written) in a clear Book" (Kor'an, 10: 62).

Mankind is Allah's Steward On Earth. Allah created mankind primarily for worship and appointed him a steward or vicegerent on earth for a purpose and for a predetermined amount of time. He is a manager, but not a proprietor or a master.

Man must protect the environment because no other creature is able to perform this task. Man was the only being that Allah entrusted with the duty of 
vicegerency on earth. This duty of trusteeship is so onerous and burdensome that no creature would accept it but man. The Kor'an says: "Truly, We did offer Al-Amanah [the trust or responsibility] unto the heavens and the earth and the mountains, but they declined to bear it and were afraid of it. But man bore it. Verily, he was unjust and ignorant" (33: 72).

The Creation of Mankind. The Kor'an informs that Allah created Adam, our father, from the clay of the earth and settled him in paradise:

And it is He Who has created man from water. (25: 54)

And indeed We created man [Adam] out of a strain of clay [water and earth]. (23:12)

He it is Who has created you from clay. (6:2)

And among His signs is this, that He created you from dust, and then, behold, you are human beings scattered! (30:20)

Verily, the likeness of Jesus in Allah's Sight is the likeness of Adam. He created him from dust, then [He] said to him: $\mathrm{Be}$ ! And he was." (3:59)

Allah, the Aimighty, therefore created man and gave him the ability to learn and talk so that he may be able to perform his functions as steward or vicegerent of the earth. The Holy Book says:

Behold, thy Lord said to the angels: 'I will place a vicegerent on earth.' They said: 'Wilt Thou place therein those who will make mischief therein and shed blood? Whilst we do celebrate Thy praises and glorify Thy Holy Name?' He said: 'I know what ye know not." (2: 30)

And he taught Adam the names of all things ... (2: 31)

[Allah] said: 'Get you down, one of you an enemy to the other (i.e., Adam, Eve and Satan, etc.). On earth will be a dwelling-place for you and a resource, for a time. (7:24) 
The Kor'anic account of the Creation of the first man (our father Adam) is similar to the Biblical one. The Kor'an informs that man was created from the dust of the earth and was granted, upon his creation, a dwelling in Paradise (the Garden of Eden):

And O Adam! Dwell you and your wife in Paradise, and eat thereof as you both wish, but approach not this tree or othenwise you both will be of the sinners. $(7: 19)$

Then, the Satan made them slip therefrom, and got them out from that in which they were. We said: 'Get you down, all, with enmity between yourselves. On earth will be a dwelling place for you and a resource for a time. (2:36)

Therefore, because of their disobedience to Allah, Adam and Eve were expelled from paradise and were sent down into a new home, the earth. But the Bible and the Koran differ in stating the role and purpose of man on the earth. Unlike other religions, Islam assigns to mankind earth stewardship or vicegerency functions which are part of its worship functions. This means that man is the steward of Allah's property, the earth, not its master or proprietor and that he is entrusted with the conservation of all creation on it. As a reward, man was allowed full use of its resources, but only in a rational manner which would sustain the earth.

The medieval historian Lynn White in 1967 wrote an essay entitled "The Historical Roots of Our Ecologic Crisis," in which he argued that Judaism and Christianity posited a dichotomy between humans and nature. According to the texts sacred to both religions, in White's view, humans were masters--not members--of the natural world. Moreover, White stated, Jews and Christians alike have traditionally believed that the rest of creation existed solely for human benefit. White found evidence for his thesis in God's command in 
Genesis (1:27-28): "Be fruitful and multiply, and fill the earth and subdue it; and have dominion over the fish of the sea and over the birds of the air and over every living thing that moves upon the earth." As White saw it, this was all the rationale believers needed to exploit nature at will. Meaningful changes in the relationship between humans and nature would not occur, he asserted, "until we reject the Christian axiom that nature has no reason for existence save to serve man" (White, 1967, p. 1207).

White's essay "touched off a storm of controversy in the late 1960s, which must be understood as a function of so-called countercultural disenchantment with established institutions as well as misgivings in the Christian community about its contribution to contemporary social and environmental problems" (Nash, 1989, p. 236). Although White agreed that there was a basis for environmentalism in the Bible, "his point was that for nearly two thousand years the Christian tradition had not been so construed. Instead people used Scripture to justify the exploitation of nature in the same way that defenders of slavery used it to justify the ownership and exploitation of certain classes of humans" (Nash, 1989, p. 89).

According to Islam, the Divine rationale for the existence of mankind on the face of the earth is this: man was created to worship the only God, Allah, and was placed on earth to settle thereon and to make use of its resources generation after generation, but for a certain period only, until the time comes for Allah to redeem the earth and that which is on it. In so doing, the Almighty gave man stewardship authority over all things created by Him, for his welfare and benefit (MEPA, 1983; Bakhashab, 1990):

I have only created Jinns and Men that they may worship Me. 
No sustenance do I require of them, nor do I require that they should feed Me. (Koran, 51: 56-57)

And surely, We gave you authority on the earth and appointed for you therein provisions [for your sustenance]. Little are the thanks you give. (Kor'an, 7:10)

Islamic Culitural Ecology. It was Ibn Khaldun, the great Islamic historian and social philosopher (1332-1406 A.D.), who laid the groundwork not only for modern sociology but aiso for cultural ecology. He described in detail the relationship between man as a cultural organism and his environment, and asserted that social organization is necessary for the human species. The individual human being, he argued, is weak, defenseless and incapable of securing by himself a minimum supply of food. Given the ability to think and hands thai can manipulaie insiruments, however, men may cooperatively obtain nourishment, provide for their defense and settle the world with their numbers. According to Ibn Khaldun (1967), only tribes held together by group feeling can live in the desert.

The concept of cultural ecology, as introduced by Steward, refers to cultural adaptation to the environment; it is described as a methodological tool to ascertain how a culture may facilitate certain changes in order to adapt to its environment (Steward, 1955). Islamic cultural ecology, then, is a concept which means Islamic cultural adaptation to the environment.

Islam was revealed to the prophet Mohammad (Pbuh) in Mecca, which is located in a barren valley in western Arabia. Scarcity of resources made pagan Arabs of Mecca practice female infanticide (wa'ad al-banat, literally meaning burying girls alive) as a population control method. Islam cancelled these ugly practices, for Allah decreed in the Holy Koran: "And kill not your 
children for fear of poverty. We provide for them and for you. Surely, the killing of them is a great $\sin ^{n}(17: 31)$.

Islam as a religion, and as a way of life, is neither revealed nor adapted only to a certain environment. Instead, it is a religion in which believers from various environments adopt its doctrines according to their local environmental conditions. The principal aspect of Islam--belief in the Oneness of God--should be independent of any particular environment.

Four of the five "pillars of Islam"--Salat (the five daily prayers), Zakat (the charity tax), Sawm (fasting during the month of Ramadan) and Hajj (pilgrimage to Mecca once in a lifetime)--are flexible in respect to their prerequisites as well as to their performance. For example, ablution using clean water is a hygienic prerequisite before every prayer, but in places where water is not available or is scarce, tayamum, ablution with earth, is substituted.

Protection and Conservation of Basic Natural Resources. Allah's wisdom has ordained that creatures shall serve each other, and that all Creation shall be in the service of mankind. The authors of the Basic Paper on the Islamic Principles for the Conservation of the Natural Enviornment explained that the Glorious Koran had decreed that each known or unknown creature in the universe performs two major functions: a religious function in so far as it evidences The Maker's omnipresence, wisdom, omniscience and omnipotence, and a social function in the service of mankind (MEPA, 1983).

Although the social function of the Creation is important in Islam, its primary function remains religious. Ibn Taymiyyah, one of the greatest Islamic scholars, stated this opinion in the following terms:

When reading the verses '... and He maketh the ships to be 
of service unto you, that they may run upon the sea at His command and hath made of service unto you the rivers; and maketh the sun and the moon, constant in their courses, to be of service unto you and hath made of service unto you the night and day. And He giveth you all ye ask of Him, and if ye would count the bounty of Allah ye could not reckon it (Kor'an, 14:32-34); or other verses in which Allah explains that $\mathrm{He}$ created the creation for the children of Adam, it must be remembered that Allah in His great wisdom created these creatures for reasons other than His serving man. Indeed Allah's reasons were greater than serving man, for in these verses He only explains the benefits of these creatures to him (man). (1988, vol. 11, pp. 96-97)

Water. Allah created water as the source and origin of all life: "And We have made from water every living thing" (Kor'an, 21:30). Because of this special imporiance, water was mentioned 63 times in the Kor'an, the sea 41 times and river or rivers 54 times. Plants, animals and man all depend on water for life and subsistence. Allah says: "Behold! ... In the rain which Allah sends down from the sky, and the life which he gives therewith to an earth that is dead ..." (2: 164). He also says: "It is He who sends down rain from the sky and with it We bring forth the plants of all kinds ..." (6:99). Further: "He it is Who sends down water from the sky; from it you drink and from it [grows] the vegetation" (16: 10).

The Lord tells man that he should appreciate, and be thankful to Him, for the bounty of fresh water; othenwise, he must suffer the consequences: "Tell Me, the water that you drink. Is it you who cause it from the rainclouds to come down or is it We? If We willed, We verily could make it salty; why then do you not give thanks to Allah?" (56:68-70). The Almighty said: "Say [O Mohammad]: 'Tell me! If [all] your water were to be sunk away, who then can supply you with flowing water?' " (67: 30). He also said: "And We sent down 
from the sky water in [due] measure, and We gave it lodging in the earth, and verily, We are able to take it away" (23: 18). Water has a further socio-religious function to perform, which is purgation of the body and clothes from all dirt, impurities and defilement so that man may encounter Allah clean, pure and purged (MEPA, 1983). In the first revelation to Mohammad (Pbuh) about his prophecy, Allah commanded his appointed prophet to clean his clothes. Sura al-Moddaththir states: "1) O you [Mohammad] covered [in garments]! 2) Arise and warn! 3) And your Lord magnify. 4) And your garments purify." (74:1-4) Also, Sura 8 , verse 11 states: ". . . and He caused rain to descend on you from the sky, to clean you thereby."

Allah has also shown mankind other functions of water in rivers, seas and oceans. It is the suitable biotope for many creatures which play vital roles in the development of the world and the perpetuation of life. Allah said: "... and He it is who has subjected the sea, that ye eat thereof fresh tender meat (i.e., fish), and that ye extract therefrom ornaments to wear. And ye see the ships therein that plough the waves, that ye may seek thus the bounty of Allah" (16:14). Therefore, marring the vital and social functions of this resource, whether by depleting, spoiling or polluting it with any material that it would make it an unsuitable environment for any living organism or any such attempts to mar its functions as the source of life, will lead to a complete halt or cessation of life itself. The Islamic rule (figh) is that "what leads to the forbidden is itself forbidden" (MEPA, 1983).

Due to the importance of water as the main source of life, Allah made it a common resource for all human beings and all creation. All creatures are entitled to use it without monopoly, compulsion, coercion, corruption, excessive 
use or abuse. Allah said (concerning the she-camel of the Thamud people: "And inform them that the water is to be shared between [her and] them. Each one's right to drink being established [by turns]" (Kor'an, 54:28). Also, narrated Abu Daoud, the prophet said: "People are partners [or share] in three things: water, pasture and fire (meaning wood and other energy resources)." Excessive and wasteful consumption of water was prohibited by the prophet whether it was abudant or scarce. Ahmed Bin Hanbal narrated that the prophet passed by Sa'ad while he was doing ablution and said to him: " 'O Sa'ad! Why all this extravagance?' Sa'ad said: 'Is there extravagance in ablution?' The prophet said: "Yes, even if you were [living] by a running river."

Air. Air is just as important as water in the perpetuation and preservation of life. The air also has other important functions to man, who was made aware by the Glorious Kor'an that he was created by Allah for a purpose. Pollination is an example. Allah says: "And We send forth the winds that fecundate, then caused the water to descend from the sky..." (Kor'an, 15:22). lbn Kathir (1993) narrated explanations of this verse which meant both plant and cloud fecundation, but did not give scientific explanations due to the state of knowledge in the ninth century, when his book was written (Vol. 2, p. 529). Maurice Bucaille, in The Bible, the Qur'an and Science, noted also that there are two possible interpretations of this verse but, in addition to the fertilization of plants, he said that, "this may, however, be a figurative expression referring by analogy to the role the winds play in the process whereby a non-raincarrying cloud is turned into one that produces a shower of rain" (Bucaille, 1979, p. 174). It is also possible, however, that what is meant here is a different figure of speech: namely, reference to the important role atmospheric winds play in 
transporting the microscopic dust particles which are vital for the condensation of water vapor into rain drops. In either case, this only demonstrates that many passages from the Holy Kor'an have been confirmed by modern science during the twentieth century.

Another role for winds is the transport of clouds. The Koran states: "And it is He Who sends the winds as heralds of glad tidings, going before His mercy (rain) till when they have carried the heavy-laden clouds, We drive them to a land that is dead, then We cause rain to descend and thereby bring forth fruits of every kind. Similarly, We shall raise up the dead" (7:57). Winds are also clear evidence of Allah's omnipotence, bounty, provision and perfection. Allah said: "Behold! In the creation of the heavens and the earth ..., in the veering of winds, and clouds which are subjected between the sky and the earth, are indeed Aayat (proofs, signs, evidences, etc.) for people who are wise ${ }^{n}$ (Kor'an, 2: 164).

Since the air performs all these important functions, it follows that to conserve it pure and abundant is an integral part of the conservation of life itself which is one of the main objectives of Islamic jurisprudence (Shari'ah). The juristic rule is that "what fulfills and satisfies necessities is itself a necessity" (MEPA, 1983). Therefore, any human activity leading to its pollution or marring its functions or spoiling it is considered an attempt at hindering Allah's wisdom and creation. This equally hinders and cripples man's role as vicegerent on earth.

Soil. The earth was mentioned 465 times in the Kor'an, which indicates its importance for all life. Allah says: "And the earth He has set for the creatures" (Kor'an, 55: 10). Of these there are numerous references to the functions of the soils and land and their relationship with water and living resources. The Holy 
Kor'an indicates that Allah created mankind to populate and settle the earth, generation upon generation. To this end, He caused the earth to produce food and drink for their sustenance through cultivation of the soil, bringing life to hitherto lifeless soil in which no plants grew with the water which He caused to descend from the sky. He then brought forth the seeds which constitute man's main food (Al-Tabari, 1953; Ibn Kathir, 1993). The Holy Book states: "And Allah sends down water from the sky, and gives therewith life to the earth after its death: verily in this is a sign for those who listen" (16:65). Further: "See you not that Allah sends down water from the sky, and then the earth becomes green? Verily, Allah is Kind and Well-Acquainted with all things" (22: 63).

The soil is not only the source of man's origin (Allah created man from clay), but is also a crucial liie suppori system. it supports plant and animal life and is the origin of the principal food resources for humans and animals. Since soil is formed very slowly by physical, physiochemical and biological processes, centuries may be needed for its reconstitution if it is destroyed or degraded. Because the soil is one of the components of the environment entrusted to mankind, humans must act with care to preserve, conserve and protect it from degradation and pollution:

The vegetation of a good town comes forth [easily] by the permission of its Lord, and that which is bad, brings forth nothing but a little with difficulty ... (Kor'an, 7:58)

... So eat and drink of the sustenance provided by Allah and do not evil or mischief on the land. (Kor'an, 2:60)

O mankind! Eat of that which is lawful and good on the land. (Kor'an, 2: 168) 
The Lord enjoins man to eat lawful things, and since maintaining soil for cultivation is a prerequisite to obtaining a good and clean crop, one can deduce that soil maintenance is wajib, or mandatory.

Islam provides rewards for care of the soil, as the prophet Mohammad (Pbuh) stated that "Any Muslim who plants a tree or a crop to be eaten from by a bird, or a human or an animal, is considered a charity given by him." The prophet also said: "If the end of the world (al-Sa'ah) comes and one is planting a tree shoot, then if he could plant it before standing up, he should do so." He also said: "He who shall bring life to a lifeless land shall have it for himself." The second Caliph, Omar Ibn Al-Khattab said: "Do not excavate (or uncover) the face (soil) of the earth because its wealth is in its face."

Finaliy, the soil is one of the signs of Allah which man must appreciate and give thanks for. The Almighty states in the Kor'an, Sura 36, verses 33-35:

A sign for them is the land (soil) that is dead. We do give it life, and produce grain therefrom, of which ye do eat. And We produce therein orchards, with date-palms and vines, and We cause springs to gush forth therein: that they may enjoy the fruits of this (artistry); it was not their hands that made this: will they not then give thanks?

Fauna and Flora. Islam looks upon fauna and flora in two ways: as living creatures in themselves performing the function of worship and attesting to Allah's wisdom and omnipotence, and as creatures playing a vital part in the development of the world in the service of man and the other creatures. From this arises the necessity of conserving and developing them for their own sake and for the benefit of all creatures, including mankind (MEPA, 1983). 
In many verses the Holy Koran makes clear the importance and great benefit of plants and animals for mankind, including their aesthetic and decorative functions. Allah says:

Verily! We have made that which is on earth as an adornment for it, in order that We may test them (mankind) as to which of them are best in deeds. (18: 7)

Beautified for men is the love of things they covet; women, children, much of gold and silver (wealth), branded beautiful horses, cattle and well-tilled land. This is the pleasure of the present world's life; but Allah has the excellent Return with Him. (3:14)

The Holy Koran mentioned the other mandatory functions of worshiping Allah, declaring His praise and bowing down to Him. Allah said:

See you not that to Aliah prostrates whoever is in the heavens and whoever is on the earth, and the sun, and the moon, and the stars, and the mountains, and trees, and animals, and many of mankind? (22: 18)

The seven heavens and the earth and all that is therein, glorify Him and there is not a thing but celebrates His praise, but you understand not their glorification. (17: 44)

Ibn Kathir commented upon this verse, saying that it "means that all creatures praise Allah since the words 'the seven heavens and the earth and all that is therein' include all creatures, but man cannot understand the praise of these creatures since it is in languages other than his own" $(1993$, vol. 3, p. 41). The Holy Kor'an also states: "And unto Allah [alone] falls in prostration whoever is in the heavens and the earth, willingly and unwillingly, and so do their shadows in the mornings and in the afternoons" (13: 15). 
Islam mandates that all measures should be taken for the protection of the life and well-being of these creatures in order that they can fully perform the functions assigned to them, for Allah considers them living communities exactly like mankind (MEPA, 1983). He said: "There is not a moving [living] creature on earth, nor a bird that flies with its two wings, but [forms part of] communities like you. We have neglected nothing in the book, then unto their Lord they [all] shall be gathered" (Kor'an, 6: 38).

Mohammad, (Pbuh) the prophet of islam, is the first conservationist in history. Allah sated: "And We have sent you (O Mohammad) not but as a mercy for the 'Alamin' (Mankind, Jinns, and all that exists)" (Kor'an, 21: 107). This is evident in numerous situations when he made statements concerning the ecology. For example, Omar Ibn al-Khattab, the second caliph of the prophet, said: "I heard the prophet say: 'Allah created one thousand ommah (groups or communities); of those six hundred in the sea and four hundred in the land, and the first one that becomes extinct is the locust nation and when it does, the rest will follow like a series when its string is cut.' " (Ibn Kathir, 1993, vol. 2, p. 124). This statement shows that the prophet was aware of the interrelationship of all organisms. Also, the prophet of Islam has shown, through his commandments and teachings, how to rear and conserve these creatures correctly.

The books of Al-Bukhari and Muslim are the two most trusted on the prophet's sayings and traditions. These two sources narrated the following. Mohammad (Pbuh) told of a woman who went to Hell because of a cat she locked up without feeding it or releasing it to feed on vermin of the earth. The prophet also spoke of a man who saved a dog from death by giving it water to drink; Allah was pleased with him and forgave all his sins. He further told of the 
prophet who ordered an entire colony of ants burned down in retaliation. Allah taught him in rebuke: "Thou hast destroyed a whole nation that celebrates Allah's praise for an ant stung thee." Mohammad (Pbuh) forbade leaving animals to starve, damned a group of people who used a bird as a target and prohibited the cutting of trees in the desert because they provide a valuable service to other creatures through their shade.

Aggression against the blessings provided by all creation, directly or indirectly, is therefore indeed an expression of ingratitude by man towards the Lord. Such aggression against animal and plant species may take two forms: indirect, through the degredation and destruction of their habitats (such as by the introduction of alien species) and direct, through over-exploitation.

Islamic Systems For The Protection and Conservation of The Envirenment. Conservation of the environment effectively depends on the implementation of conservation systems, which divide available resources among the population in a fair and sustaining manner. The Islamic approach to environmental protection has proved capable of creating sustainable natural resource management of a most sophisticated kind (Burhenne, 1989). The following is a survey of some Islamic resource management systems.

Ihia'a al-Mawat. This literally means bringing a dead land to life. It was established by Islamic jurisprudence (Shariah) that he who brings a dead land to new life by cultivation, or any other useful means, can rightfully claim it as his. Guidelines governing this system include the principle, however, that such ownership of land is not recognized if the activity on it harms or interferes with the public welfare (MEPA, 1993). 
Al-Hema. The Arabian hema grazing system is probably the world's oldest effective one of range conservation (Draz, 1985). It is based on a philosophy of protection and improvement instead of exploitation. The hema system represents the maintenance of reserves, such as those set aside by tribal groups from the open rangeland, to protect them from overgrazing (Burhenne, 1989).

The prophet Mohammad (Pbuh) was concerned with fodder reserves because they preserved the strength of the Islamic nation. He protected Hema Alnakila (a wadi near Al-Madinah), which was used mainly by animals, to defend the cause of Islam. The prophet is known to have said: "Hema is only for Aliah and His prophet." This saying has been interpreted to mean that a governor or an Islamic state is allowed to protect the hema in the best interests of the community (Draz, 1985). He also granted the Al-Azd tribe a written promise to keep their hema near their town. It was maintained for fourteen centuries, until the 1970s (Al-Zelfah, 1994).

Types of Hema. Draz explained that ahmia (protected areas) may be classified according to the following five types of protection. In the first, animal grazing is prohibited, but the cutting of grasses is permissible during specified periods and droughts. The head of the tribe grants special privileges for a limited number of needy people to use the reserved range. A specified number of persons from each family are allowed to cut mature grass during the season. In the second, grazing and/or cutting is permitted, but restricted to certain seasons of the year. Grazing is allowed year-round in the third, and the kind and numbers of animals permitted to graze are specified. In the fourth the reserve is set aside for bee-keeping. There is a limited number of these ahmia, 
and grazing restrictions are relaxed after the flowering season. The aim of the fifth is to protect wood trees such as juniper, acacia or ghadha (Haloxylon persicum). Hema Unayzah, which is 40 by $70 \mathrm{~km}$. in area and is located in the heart of the Najd plateau, has been protected for many centuries. This is the principal one of few biotopes in the world where the ghadha species grows. Draz (1985) mentioned that this hema has the unique objective of protecting Haloxylon persicum trees for the effective stabilization of moving sand dunes adjacent to Unayzah. However, from the author's first-hand experience as a citizen born and raised in this city, it can also be said that the principal objective for conserving this natural resource is its excellent economic and energy value as a firewood.

The Two Holy Miosques (Haram). The areas around the two Holy Mosques in Mecca and Al-Madinah in Saudi Arabia had been designated as special protected areas (ahmia) for many centuries. Mecca was protected by the prophet Abraham, while Al-Madinah was protected by the prophet Mohammad, (Pbuh) which makes them the first protected zones in the world, long before the advent of the current global protected zones system initiated by the creation of Yellowstone National Park in 1872 (Al-Welaie, 1994).

The area around Mecca is a safe haven (haram) for both people and wildlife. Hunting animals and cutting wild trees are forbidden. It is also forbidden to harm wildlife in and around Al-Madinah. The prophet of Islam once said: "Abraham forbade Mecca and I forbid Al-Madinah; no plant is to be cut, and no game is to be hunted" (MEPA, 1993, p. 31).

Religious Endowments (Waqf). Islam encourages individuals to participate in the conservation and wise development of the environment, through gifts, 
wills and all types of lending (MEPA, 1993). One of the most important systems in this field is the philanthropic religious endowment, which is basically a private donation for public welfare. Omar Ibn Al-Khattab, the second Caliph, obtained a piece of land in Khaybar, a town near Al-Madinah. He asked the prophet what to do with it and Mohammad (Pbuh) told him that if he wished, he could keep the title (deed) and give it to charity. Omar did this, deciding that it was not to be resold, given as a gift or inherited; he gave it as an act of charity to the poor, to travellers and others.

Waqf can be in the form of land set aside for philanthropic purposes, such as agricultural or range research, a wildlife refuge, a source of wood for a community, a water source or simply a public park. It can also be in the form of real estate financing of conservation projects. Governors and heads of states can set conditions and criteria for these endowments and attending supenisors (MEPA, 1993). 


\title{
CHAPTER FOUR
}

\section{CITIZEN PARTICIPATION IN ENVIRONMENTAL AFFAIRS IN ISLAM:}

\author{
THE CASE OF SAUDI ARABIA
}

Islam, the official religion of the people and government of the Kingdom of Saudi Arabia, provides general, broad and encouraging principles for citizen participation in governmental environmental affairs. The Fifth Development Plan of the government of Saudi Arabia stressed that "the citizen's role and cooperation in conserving and preserving the environment is essential and has no substitute" (MOP, 1990, p. 392). However, no governmental policy has existed to date that institutionalizes the role of citizens' environmental societies in environmental work.

Very little research has been conducted on citizen participation in this area either in Saudi Arabia or in western nations, the United States in particular. Wengert noted the following concerning the case of the United States:

It is probably not suprising that neither normative nor empirical theories applicable to the topic [of citizen participation] have been formulated. Little research on the subject has been undertaken, and even as speculative philosophy the ideology of participation has not been systematically organized or neatly structured. (1976, p. 23) 
Ahmed H. Dahlan (1990) wrote a comprehensive article which outlined the framework of citizen participation in Saudi Arabian local government. He complained that, in Saudi Arabia, little research had been done on the subject and that the issue, on the whole, had mostly been either neglected or treated inadequately even in studies by experts in public administration and political science. Al-Rawaf (1980), for instance, did not explain the Islamic foundations of citizen participation. Al Sabban, in his exhaustive study of the Saudi municipal system, raised the issue of participation but did not follow through with any discussion of its implications.

The Meaning of Citizen Participation. Political scientists have not agreed upon what constitutes citizen involvement, either what it is or what it should be. Wenger wrote:

Although the participation phenomenon may be worldwide, its meaning, role, function and imporiance vary from culture to culture and political system to political systrem. It also seems evident that the drive or reasons for seeking more participation vary, depending on the perspectives from which the subject is approached, the institutional, politicl, economic context, and the personal interests and points of view of those opposing as well as supporting participation. Similarly, the phrases 'public participation' and 'citizen involvement' have many meanings and connotations, depending on the situation to which applied and the ideology, motivations, and practical orientations of the users. (1976, p. 23)

This observation applies to the meaning of citizen participation as it has been defined by some western scholars and by a sample of Saudi Arabian citizens. Weiner gave the following definition:

Any voluntary action, successful or unsuccessful, organized or unorganized, episodic or continuous, employing legitimate or illegitimate methods intended to influence the choice of public policies, the administration of public affairs, or the choice of political leaders at any level of government, local 
or national. (1971, p. 164)

Verba defined the concept as "those legal acts by private citizens that are more or less directly aimed at influencing the selections of governmental personnel and/or the actions that they take" (1978, p. 1).

Ahmed Dahlan (1990) asked a sample of forty Saudi students studying in the United States what their understanding of citizen participation was. He found that it means a number of different things to them, among these: giving advice and offering suggestions; holding jobs in a program and performing the work in a sincere and effective way; making decisions within an administrative or political framework; having an influence on decision-making; and assessing the activities and output of governmental institutions or any action that affects the public interest. For the Saudis sampled, the rationale for participation is that it can affect outcome, on the local and national levels. Similar results were obtained in a survey conducted for this thesis.

The Importance of Citizen Participation in Environmental Work in Saudi Arabia

Dahlan explained eight advantages that can be achieved only through citizen participation. Among these are, first, that the more citizen participation is constitutionalized and institutionalized, the closer the government is to legitimacy. Second, citizen participation in public activities is one method that can help maintain a reasonable degree of social, economic and political equality. Third, participation is an important source of the information needed for any policy or decision made by government, if it is to be successful. Fourth, organizational goals are more likely to be reached effectively and efficiently 
when all members of an organization participate. The same is true at the provincial level as well as the local government level, where a citizen is not only part of the community but also is greatly affected by the policies, programs and decisions made regarding his needs and welfare. King AbdAl-Aziz Al-Saud emphasized this fact during his address to the citizens of Mecca in 1924.

Fifth, if the citizens and government pay more attention to the benefits of participation, draw a sincere and astute policy and establish appropriate programs, not only will participation "lead to a more accurate and clear direction for the most needed services, but it will also save money, efforts and time by reducing investigation to find out what kind and where the services should be established" (Al-Saflan, 1981, p. 49). Sixth, and finally, the most important imperative for participation in the affairs of the state is that this is a fundamental right of every Muslim. Abul A'la Al-Mawdudi explained that,

According to Islam, governments are representatives of the Creator of the universe; this responsibility is not entrusted to any individual or family or to any particular class or group of people, but to the entire Muslim community. The Holy Kor'an ... clearly indicates that khilafa (succession) is a collective gift of God in which the right of every individual Muslim is neither more nor less than the right of any other person. (1980, pp. 33-34)

\section{The Environment of Citizen Participation}

The phenomenon of citizen participation cannot be studied in isolation from its environment. In order to consider the Saudi State as such a setting, a brief review of its recent political history is necessary.

Background. Saudi Arabia acquired its political entity as it is known today in 1926, when King AbdAlAziz Al-Saud consolidated tens of small city-states in a 
torn and fragmented territory into one country. It can be said that through King AbdAIAziz, "an effective territorial state was superimposed upon the old tribal structure and had to a large extent, replaced it" (Lipsky, 1959, p. 16). Ahmed Dahlan (1990) argued that this history must be borne in mind when discussing the issue of citizen participation in Saudi Arabia today. He added that after the decline of the Othman Empire in the thirteenth century, most of the Arabian peninsula existed without government by a state. This condition negatively affected both past and present educational, economic and political institutions, and in turn hindered citizens from establishing, developing or participating in any types of stable and sophisticated government of any notable size. However, many necessary elements were present in tribal and local politics and in religious doctrines that later developed into positive forces of participation at the national level.

The Value System. The value system that surrounds the environment of citizen participation in Saudi Arabia has theological origins. Islam dominates the Saudi people's thinking, feeling and behavior, and provides them with a framework for their everyday actions.

Dahlan (1990) adds that a significant point in this regard is the inseparability of religion and politics in Saudi Arabia. Any activity is considered to be religious practice. Hence, citizen participation, if it complies with Islamic principles, is a type of worship. Put succinctly, participation equals worship.

In Islam, there are several different interrelated and interdependent values, beliefs and behaviors which may be identified as a framework from which to analyze and discuss citizen participation in the Kingdom. The following is a survey of the more important ones. 
The Concomitancy of Belief and Righteous Deeds. One of the most important principles in the Islamic ideology is the necessity of the concomitancy of the creed and deed. In the Kor'an, whenever the belief in Allah is mentioned, it is either preceded or followed by emphasis on the righteous deeds. Allah, the Almighty, said: " . . So whoever hopes to meet his lord, let him work righteousness, and in the worship of his Lord admit no one as partner" (Kor'an, 18:110). The prophet of Islam (Pbuh) said: "Faith is seventy and some branches, the highest of which is the belief that there is no God but Allah, and the lowest is sweeping mischief from the road." Since environmental pollution is a type of mischief, it can be deduced that Islam here joins belief in Allah with deed, and also that Islam considers environmental protection as part of faith in Allah.

The Vicegerency Theory and the Concept of Leadership. Islam affirms that, under the sovereignty of Allah, man is the representative or khalifa of Allah. AI Mawdudi explains:

According to the Kor'an, the vicegerency of God is not the exclusive birthright of any individual, clan or class of people; it is the collective right of all those who accept and admit God's absolute sovereignty over themselves and adopt the Divine code, conveyed through the prophet, and the law above all laws and regulations. (1978, p. 25)

Allah, the Almighty, said: "Behold, thy Lord said to the angels: 'I will make a vicegerent on earth' " (Kor'an, 2:30). "To illustrate what this means," AlMawdudi explains:

Let us take the case of an estate of yours which someone else has been appointed to administer on your behalf. Four conditions invariably obtain: First, the real ownership of the estate remains vested in you and not in the administrator; secondly, he administers your property directly in accordance with your instructions; thirdly, he exercises his authority within the limits 
prescribed by you; and fourthly, in the administration of the trust he executes your will and fulfills your intentions, not his own. Any representative who does not fulfill these four conditions will be abusing his authority and breaking the covenant which was implied in the concept of representation." (1980, p. 10)

Accordingly, all individuals of an Islamic nation are successors or vicegerents. Every Muslim citizen should take a role in his or her community: "A Muslim citizen has no choice or alternative but to participate, it is a duty that derives from the succession principle" (Dahlan, 1990, p. 140).

Al-Shura Principle of Government. According to Islam, for a government to be legitimate, it has to be consultative. It is not only the national government that must be consultative, but every level of government has to enforce this Divine Rule (Dahlan, 1990). Mohammad Assad explained: "Al-Shura is so comprehensive that it reaches out into almost every department of political life. . .$"$ (1980, p. 44).

The predominant opinion among Muslim jurists is that nulers and officials, including those in local government, are obligated to consult their citizens on public matters and abide by this obligation. Citizens, moreover, must express their views on matters of concern to them, even if not asked to do so. In short, the Kor'an, by expressing the concept of Al-Shura, deals precisely with the question of participation (Al-Rawaf, 1980, p. 13). The prophet of Islam (Pbuh) said: "Faith is advice." When asked, "O prophet of Allah, to whom?" he replied: "to Allah, to His book, to His prophet, to the leaders and to all Muslims."

Mutual Cooperation. Members of a Muslim society, rulers and ruled, are enjoined to cooperate in every righteous and pious matter. The Holy Kor'an ordained: "Cooperate with one another for righteousness and piety, and do not cooperate with one another on sin and aggression" (5:2). 
The Messenger of Allah (Pbuh) said: "The faithful are to one another like [parts of] a building, each strengthening the others," and also said: "The hand of Allah is with the group." Thus Asad asserted that mutual cooperation in all phases of life is a fundamental requirement of Islam and no state can be called an Islamic state unless it guides that cooperation by legislative means, and thereby enables its citizens to live up to the demands of Islam (1980, p. 89).

The Duty of Moral Belief and Behavior. The citizen is duty-bound to combat evil wherever he encounters it and to strive for justice whenever people disregard it (Asad, 1980, p. 81). The Kor'an states this very clearly: "Let there arise out of you a group of people inviting to all that is good, enjoining what is right, and forbidding what is wrong; they are the ones to attain felicity" (Kor'an, 3:104).

The prophet (Pbuh) said: "By Him in whose hand I repose! You must enjoin right and forbid wrong, or else Allah will certainly send down chastisement upon you; then you will call to Him, but He will not respond to you." And said: "The highest kind of Jihad (holy war) is to speak up for truth in the face of an aggressive governor (or government)." And said: "If any of you see something evil, he (or she) should set it right by his hand; if he is unable to do so, then by his tongue; and if he is unable to do even that, then within his heart, but this is the weakest form of faith."

In conclusion, it is the duty and right of the citizen to participate in all governmental activities, including environmental affairs. Raising one's voice against manifest wrong, for example, is considered one of the foremost duties of a Muslim, and particularly so when the action occurs on the part of governmental officials (Asad, 1980, p. 77). 


\section{The Institutional Environment}

Ahmed Dahlan (1990) identified five types of institutions, some traditional and others more recent, through which Saudi citizens participate. These are: 1) the Mosque, 2) the open Majlis or Council, 3) the Municipal Council, 4) the Neighborhood Councils, and 5), the mass media.

Although some political scientists considered the open Majlis (where citizens gain access to power) the keystone of the political system of Saudi Arabia (AlRawaf, 1980), others have observed that it is an inefficient method for citizen participation (Dahlan, 1990). The mass media, especially newspapers, have been increasingly used by citizens to convey needs and demands, suggestions and advice, and constructive criticism to top officials both at the national and local levels of government. During the last eight months, the author sent three critical articles on environmental issues to Al-Riyadh newspaper in Saudi Arabia, and they were all published.

The following is a survey of some other important systems of citizen participation.

Al-husbah System. This is a unique and comprehensive Islamic system for citizen participation in government, which has been neglected, not only by most Islamic scholars, but also by modern governments of the Islamic world. This institution was founded by the prophet of Islam, Monammad himself, as a citizens' volunteer reform system. It was years later that the Islamic state officially adopted the system and appointed an employee called al-mohtasib to do this work. 
Ahmed Ibn Taymiyyah (661-728 H), who wrote a book entitled Al-Husbah in Islam, stated that al-husbah is fardh kifa'yah, meaning mandatory upon some qualified Muslims. It becomes fardh ain, meaning mandatory upon every qualified Muslim, when not done by others.

Al-Bogomy (1994) and Al-Garny (1994) wrote two comprehensive books on al-husbah. They surveyed all definitions of it by islamic scholars and stated that they found slight variations. However, Al-Garny suggested a definition for the term which takes into account all others: "al-husbah is work done by a Muslim to change a manifest disorder or to order a neglected righteous deed, via official authority or volunteer efforts, but the one officially charged has more authority than the volunteer" (pp. 63-64).

Al-Hugail (1992), Al-Bogomy (1994) and al-Garny (1994) outlined the differences between the authorized muhtasib (the person doing al-husbah) and the volunteer as follows. First, when the state appoints men to do this job, alhusbah becomes a personal duty fardh ain on them. In the case of the volunteer muhtasib, it is fardh kifa'yah (a duty that must be performed by some unspecified members of the community), and becomes mandatory duty upon him only if it is not done by others and he is qualified to do it. Second, the appointed muhtasib cannot be engaged in doing other work, while the volunteer can. Therefore the appointed muhtasib is paid by the state, while the volunteer is not. Third, the appointed muhtasib can be sought for grievance and assistance, and he has to respond to a plea, but the volunteer cannot. Fourth, the state muhtasib must search for and investigate visible disorder and abandoned performance of righteous deeds, but the volunteer does not have to. 
Fifth, the state muhtasib can impose punishment that does not reach the level least declared by Islamic jurisprudence, but the volunteer cannot. Sixth, the state muhtasib can employ deputies to aid him in his work, but the volunteer cannot. This, in the author's opinion, is meant to exclude a command function because only the state has authority. It is possible, however, for a group of volunteers to come to the assistance of each other in any non-governmental organization to perform in accordance with the al-husbah system.

The Functions of al-Muhtasib. The functions of the Muhtasib are numerous and diverse. Al-Hugail (1992) reported six major functions, which include remedying disorder and mischief and monitoring public manners and behavior. Also involved is the monitoring of public places to protect public health--such as hospitals, hotels, restaurants and public saunas (hammamat)--and professions that impact public health--such as bakers, butchers and chefs--to make sure that environmental health regulations are observed. Monitoring markets, weights and measuring devices, and all kinds of cheating, monopolies and usury in sales is also conducted.

Al-Hugail (1992), Al-Bogomy (1994) and Al-Garny (1994) reported that many of the functions and jurisdictions of the State Muhtasib became functions of several governmental organizations in the modern Islamic states. Al-Hugail added that "we wish to note that this distribution of functions and jurisdictions in modern times, involves the state appointed Muhtasib only" (p. 29).

Mohammadain (1994) commented that it was a reason for pride in the value of the system that the Crusaders, after they took over Palestine, maintained the position of Muhtasib due to its vital role in providing environmental security. 
Consultative and Provincial Councils. These are the most recent institutions through which citizens can participate. King Fahd bin AbdalAziz re-established in 1992 the Majlis Al-Shura (Consultative Council) and the Provincial Councils. Although the members of the Consultative Council were not elected, limited participation can be accomplished. This is through a provision which gives the Council's Committees the right to request assistance from non-members. The thirteen Provincial Councils are each chaired by the Governor of the Province and include, in addition to the heads of Provincial governmental departments, ten citizens from the province.

Citizen Participation Through Non-Governmental Organizations. This is another avenue in the Kingdom of Saudi Arabia through which citizens can participate in local, national and international governmental affairs. A nongovernmental organization (NGO) is a term used to describe what is known in many nations as community, citizen, public interest or volunteer groups (Starke, 1990, p. 185).

Models of Nen-Governmental Organizations in Saudi Arabia. In Saudi Arabia, many non-governmental organizations are found. At least three types can be identified as operating within the Kingdom. These are the philanthropic (khayri'yah) and the cooperative (ta'awuniyah) societies which are licensed through the Ministry of Labor and Social Affairs, and the disciplinary (elmiy'ah) societies which are licensed by the state universities.

The Philanthropic Societies. The eleventh item of the Basic Government Policy of the Kingdom of Saudi Arabia states: "The Saudi society conducts itself on the basis of faith in Allah, cooperation in philanthropy and piety, and solidarity with each other." Item 27 states: "The state guarantees the rights of 
the citizen and his family in cases of contingency, sickness, disability and old age ... and encourages organizations and individuals to participate in philanthropic work."

The Fifth Development Plan of the government of Saudi Arabia (1990-1995) recognized three ways in which the private sector can play a role in environmental protection. The third of those is sponsoring environmental conservation projects. The plan states: "in this regard, the establishment of effective channels for private support of enivironmental efforts (such as foundations) would be an important private sector initiative" (MOP, 1990, p. 394).

There are many local, national and international philanthropic societies in Saudi Arabia. Examples of these, respectively, are the Al-Salhi'yah Philanthropic Society, the Smoking Abatement Philanthropic Society and the King Faysal Philanthropic Foundation. These organizations are licensed by the Ministry of Labor and Social Affairs in Al-Riyadh, and obtain their mandate and impetus from the solidarity principle of Islam and the principles mentioned earlier in this chapter. Documents obtained from the Ministry of Labor and Social Affairs were scanned; the following is a translation of some items of the policy for philanthropic societies and foundations (MOLSA, 1990, pp. 179-191), which was approved by the Council of Ministers Resolution No. 107 dated 25/6/1410 H:

Item One: a philanthropic society is established when a request is submitted by twenty Saudi citizens or more, who have no criminal record, and after approval from the Ministry of Labor and Social Affairs (MOLSA)... 
Item Two: the philanthropic society aims at providing social services, and educational, cultural, and hygienic human services that arenot for profit ...

Item Four: The MOLSA issues to the society a certificate which includes date and number of registration ...

Item Six: The society consists of the following:

1. The general assembly.

2. The managing board.

3. The permarient committees.

Item Eleven: The society must:

1. Keep at its administering office the documents, correspondence, and records belonging to it

2. Record in a special record the name, age, profession, address, date of membership and fees paid by every member and any subsequent changes to this information.

3. Keep in a special record the minutes and decisions of meetings of the assembly and the managing board...

4. Record in detail all expenditures and income including contributions and their sources.

5. Have a certified public accountant.

6. Deposit all monetary assets in its name in one of the banks in the Kingdom. Two authorized signatures are required for any withdrawals.

7. Place its name, number of registration, area of operation in all of its books, records, letters and publications.

Item Twelve: MOLSA provides financial and technical assistance to the registered society. The society has the right to solicit contributions, accept gifts and inheritance wills.

Item Seventeen: MOLSA supervises the activites of philanthropic societies and monitors their compliance with this policy, ... and inspects their records and documents.

According to Ministry of Labor and Social Affairs records, there are currently 111 registered philanthropic societies in the Kingdom of Saudi Arabia. In addition, 23 societies have been licensed but not yet registered. None of these 
is an environmental protection philanthropic society, but the Smoking Abatement Society is the closest to this category.

Al-Shebaiky (1992) reported that the Ministry of Labor and Social Affairs provided 56.5 million Saudi riyals ( $\$ 15.07$ million) as financial assistance to the philanthropic societies in the year 1989/90 AD. Such assistance was only about four million Saudi riyals in the year 1975/76. She added that this indicates the great development of volunteer efforts in the Kingdom, which were represented in 1989 by 104 philanthropic societies. These included twenty women's societies, four of which were the first philanthropic societies to be established in Saudi Arabia.

According to the model charter of philanthropic societies, which was issued by ministerial decree number 3806 on $1 / 6 / 1413 \mathrm{H}$, the earnings of these societies consist of: 1) membership fees, 2) contributions, gifts and religious charity [zakaf] , 3) activities revenues, 4) government assistance, 5) inheritance wills and religious endowment [waqf], and 6) investment returns of assets (MOLSA, n.d., p. 42) There are three types of governmental assistance: annual, construction and establishment assistance payments (al-Riyadh newspaper, March 5, 1994).

A special type of philanthropic society is the private philanthropic foundation, which can be established by an individual or a group to provide social service to individuals or to certain groups for no profit (MOLSA, n.d., p. 25). These foundations, however, are not eligible to receive financial assistance from the Ministry of Labor and Social Affairs and are not allowed to solicit contributions, although they can accept gifts and inheritances. 
Two examples of philanthropic societies in Saudi Arabia are the Al-Nahdha Philanthropic Society for Women and the Al-Salhi'yah Philanthropic Society in Unayzah.

The former was established in 1962 as the first philanthropic society in Saudi Arabia. Its goal is to serve the Saudi community by developing the capabilities of women and guiding them in accordance with Islamic teachings and to organize women's philanthropic social activity through a system of sophisticated volunteer work, all for the purpose of positive participation towards achieving the goals of the national development plans (Al-Nahdha, 1993).

The current organizational structure of this pioneering society consists of the general assembly, the governing board and the secretariat general. The first is the higher authority and is responsible for electing the governing board and approving its policies before they are implemented.

The society provides activities and services in the following areas: 1) cultural, 2) vocational, 3) social, 4) hygienic, 5) child care, 6) special rehabilitation and 7) special education. It has eight specialized committees which implement the policies of the board, through nine specialized centers. These committees are: Information and Public Relations, Special Rehabilitation, Heritage and Traditional Crafts, Special Education, Culture and Arts, Social and Hygienic, Child Care, and Finance and Contributions.

The director general of the Al-Nahdha Philanthropic Society for Women stated that the society took the initiative in contacting the organizers of the Saudi Environmental Awareness Project for the purpose of participation in holding lectures and seminars for women at the society's headquarters in Al- 
Riyadh. It has also initiated a paper recycling program and urged its members, via its newsletter, to participate in the conservation of the environment (AlShu'aybi, letter to author, September 20, 1994).

The Al-Salhi'yah Philanthropic Society in Unayzah was registered in the Ministry of Labor and Social Affairs under number 52 on 24/1/1403 H. It carries the name of Mr. Saleh bin Saleh, a pioneer who established, directed and taught in the first public school in Unayzah, long before the governmental education system was created.

Many leading Saudi writers, poets, historians, scientists and governmental officials finished their primary education at this school. The current minister of education in Saudi Arabia, Dr. AbdalAziz Al-Khwaiter, is only but one of those.

Some of the graduates of this school became pioneers in their own right. For example, the author's father, AbdAllah Hamad Al-Senany, a poet, established in Unayzah, with Dr. AbdAllah Ali Al-Nu'aim, the first chairman of the board of the Al-Salhi'yah Society and former vice president of King Saud University and mayor of Al-Riyadh, and others, the first literary club or "society" in the Kingdom.

The goals of Al-Salhi'yah Philanthropic Society, as stated in one of its publications (SSCC, 1993), are: 1) community service through education, culture, support of research and inquiry, and deepening the desire for knowledge; 2) increasing the awareness of community members and future generations of the work done by their pioneer vanguards and their accomplishments in the fields of philanthropy and community development, and unleashing energies to follow their steps in ways the society sees as appropriate. 
The Disciplinary Societies. As in the case of the philanthropic societies, there are many disciplinary societies in the Kingdom of Saudi Arabia. These include the Saudi geographical, biological, chemical, historical, archaeological, economic, accounting, engineering and others. In addition, societies exist in most medical specialties, such as the Saudi heart, kidney, diabetes and anesthesia societies.

Disciplinary societies are licensed by the state universities. A document entitled "The Basic Unified Guidelines of Disciplinary Societies in Saudi Universities" was obtained from King Saud University in Al-Riyadh. The following is a translation of some of its important items:

Introduction: The Saudi universities can establish national disciplinary societies in all applied and theoretical fields, according to the procedures in this policy.

Item One: Every Saudi disciplinary society established in the Saudi universities has a special name connected with the specialty it is established for. The supervising body and its permanent location is to be defined, on the condition that the society works under the umbrella and supervision of the founding university.

Item Two: The basic goals of disciplinary societies:

1. Development of intellect in the specialty area of the society

2. Assuring communications among the members of the society.

3. Providing academic advice, in theory and application, in its specialty.

4. Raising the level of performance, academic and professional, among the members of the society.

5. Any other special goals the academic councils of the universities view as important.

Item Three: The disciplinary society works to implement the above-stated goals, and it can specifically: 
1. Conduct scientific research in its area of specialization and related areas of knowledge and publish, distribute and exchange research results with other concerned bodies.

2. Hold seminars, workshops and training sessions to study issues related to the interests of the society.

3. Produce a scientific magazine or newsletter which is concerned with publishing specialized studies and research.

4. Conduct research to develop practical applications.

Item Four: Procedures for establishing a society: establishing disciplinary societies starts at the appropriate councils in the universities; then the proposal is sent to the joint advisory committee in the Ministry of Higher Education. After approval is granted by the Minister of Higher Education, the executive decision is issued by the appropriate university president.

Item Five: Membership. There are three types of membership: honorary, working and associate.

Item Nine: Governing board. The society is managed by a board consisting of nine members, elected by the general assembly through secret election, serving for two years.

Item Thirteen: General assembly. The general assembly is composed of all working members. It holds an annual meeting, the agenda of which is prepared by the governing board. The assembly specializes in:

1. Issuing guidelines for internal work

2. Approving the annual budget and final accounts.

3. Adopting the annual report of the society.

4. Electing the chairman and members of the governing board.

5. Approving the action plan submitted by the board.

6. Deciding on matters on the agenda pertaining to the society.

7. Electing the honorary president of the society.

Item Fifteen: The society's resources and budget. The society depends primarily on self-generated resources such as:

1. Registration and annual membership fees.

2. Sales of its publications.

3. Fees from training sessions and programs, and other activities established to serve its goals. In addition, income is received from gifts, 
contributions, assistance from the goverment or public and private organizations and individuals, and the annual assistance from the university.

The following is a survey of some Saudi scientific disciplinary societies.

The Saudi Geographical Society was established in 1985 in the geography department at King Saud University in Al-Riyadh. It has been active in many areas. The society has been producing a series entitled "geographical research," and has also issued a guide to the masters' and Ph.D. dissertations from the geography departments of Saudi Arabian universities and a summary guide to some of them. It has held annual conferences and established a geographical library.

The Saudi Biological Society was established in 1975. It is located at the Botany Department of the College of Science of King Saud University. This society's stated goals include the following:

2. [To] increase interest in local environmental problems, and try to find solutions to them by holding seminars and conferences.

5. [To] promote the conservation of nature in the Kingdom.

Its major accomplishments include holding the first scientific conference on the desert in 1976, the conference on the environment of the coast of the Red Sea in 1976 and fifteen conferences since 1977 on biological aspects of the Kingdom of Saudi Arabia. It has produced several scientific publications on the natural history and biology of the Arabian peninsula and a periodical magazine entitled the Saudi Magazine for Biological Sciences.

The Cooperative Societies. This type of society is an economic and social organization designed primarily for the advancement of the economic interests of its members by supplying them with goods and services or marketing their goods and services. The Ministry of Labor and Social Affairs is responsible for 
licensing and monitoring the cooperative societies. The document entitled "Policy of the Cooperative Societies and Guidelines for Assistance to the Cooperative Societies," which was issed by the Royal Decree Number 26 , dated $25 / 6 / 1382 \mathrm{H}$, states that the cooperative societies are of five types: multipurpose, consumer, agricultural, professional and services. 


\section{CHAPTER FIVE}

\section{ENVIRONMENTAL POLICY AND ADMINISTRATION IN THE KINGDOM OF SAUDI ARABIA}

This chapter provides a general account of the administration of the environment in the Kingdom of Saudi Arabia, covering both policies and public organizations. Henning and Mangun (1989) defined environmental administration as "directing and managing public policies and activities in environmental affairs that promote and protect the public interest" (p. 1). "Environment" refers to the sum total of the biological, chemical and physical status and character of the natural world. It is the fabric of the biosphere, and as such it embraces both living (biotic) and non-living (abiotic) features, along with the processes, cycles and interrelationships which influence these. For this reason, environmental administration is interdisciplinary. The identification of and solutions to environmental problems require the synthesis of contributions from many different disciplines, including economics, ecology, sociology, physics, chemistry, engineering, systems, law and political science (Park, 1986).

\section{Environmental Policies and Requlations}


Environmental administration is an inherently difficult area of decison-making, based on complex, dynamic, multi-partcipant, multi-goal and ill-structured decision-making contexts (Bradley, 1973; Shakun, 1981). This complexity arises partly because of the many factors involved, but also because of the difficulties of evaluating trade-offs beiween alternative means of action.

Matthews and Perkowski (1975) note that all major environmental decisions are made in the broad context of meeting the different needs of society:

Society cannot simply decide, and get, what kind of environment it wants; it must also decide what it is willing to give up, or to do in addition, so that it can effect the change in the status quo which will generally be required to produce a change in the environment. (p. 214)

Policy decisions are not neutral or value free. The value system underlying decisions is an important influence when decisions are made, influencing what factors are taken into account and how alternatives are evaluated. Policy formulation is normative in the sense that it is concerned with recommendations and rules based on standards and values of society within that country (Park, 1986). The Kingdom of Saudi Arabia works on the basis that the texts of the Kor'an and Sunnah are supreme over all other texts. This means that it is not legal for the state to issue a policy that is not consistent with the texts of the Kor'an and Surinah (Al-Sudairy, 1993).

Environmental Policy Formulation

Park (1986) explained: 
Environmental decision-making spans a hierarchy of levels from the individual (place specific) project (e.g., the building of a nuclear power plant at a named site), through the more general programme (e.g., a national nuclear power programme), to the overall policy (e.g., national energy policy). At each level within this hierarchy the goals and objectives change, along with the space and time scales involved and the nature of the environmental problems and dilemmas to be resolved. (p. 27)

A policy can have many meanings; as O'Riordan points out, "it may refer to a set of guidelines or principles against which possible courses of action can be evaluated, or it may relate to a declared statement of intent to do something, backed up by the provision of an enabling budget" (1982, p. 104).

Whether it is concerned with guidelines, actions or statements of intent, Shakun (1981) sees policy making as "ihe design of purposeful systems to deliver values to participants." The specific policy instruments chosen to deliver these values may be based on positive strategies (such as education and moral persuasion) and/or negative strategies (such as laws, taxes and regulations). The wide variety of policy mechanisms fall into three main groups: moral persuasion, direct (legal) regulation, and economic incentives.

An environmental policy is thus a goal-seeking series of actions, designed to satisfy objectives normally defined by national governments. These objectives might include the conservation of wildlife, the maintenance of air and water quality and related areas. Senany (1990) defined the meaning of policy to the Saudi Arabian Development plans as: "The means proposed to achieve a particular objective or objectives; for instance, achieving the objective of improving the general health of the puppulation by means of upgrading preventive health services" (p. 127). 


\section{Saudi Environmental Policies and Requlations}

Environmental problems do not respect political, administrative or economic boundaries, and environmental policies can be formulated and implemented at a number of spatial scales. Four are particularly relevant (Garlauskas, 1975): local, national, transfrontier and international.

\section{National policies}

Park (1986) asserted that environmental policy formulation at the national level is both important and difficult. Complementing the inherent difficulties of decision-making in such a broad area are three practical problems which can only be addressed at the national level. These are:

1) The need to insure that national environmental policies are compatible (in objectives, practice and impact) both with other national policies and with the government's desired direction of change.

2) The competition to secure public funding to enable certain policy instruments to be adopted (e.g., sponsored research).

3) The need to consider the possible impacts of environmental policies on trade, investment and sector structure (at home and abroad).

Environmental policies must be formulated alongside and be compatible with, if not supportive of, other national policies (e.g., social, economic, military and strategic policies). The Fifth Saudi National Devolopment Plan (19901995) stated that "the environmental impact of actions in one sector are often 
felt in other sectors, so that harmonious environmental policies must be adopted for all sectors of the economy, and coordinated amongst many government agencies" (MOP, 1989, p. 394). A National Environmental Policy Law has been drafted by MEPA many years ago, but it has not been approved yet. The following is a survey of the national Saudi Arabian environmental policies and regulations:

a) The Basic Governing Policy. This major policy issued by Royal Decree $\mathrm{A} / 90$ on $27 / 8 / 1412 \mathrm{AH}$ includes the following items:

Item 31) The state attends to public health and provides health care for every citizen.

Item 32) The state works to conserve, protect and develop the environment and prevent pollution.

b) The National Development Plans. Al-Hakamy (1989) states that "The Kingdom began to follow development planning techniques from $1390 \mathrm{H}$. Since the first development plan, the objectives have been comprehensive as they included ... environmental and natural life preservation, and the interrelation between the environment and development (p. 2). TheFifth Development Plan outlined the following eight policies for coordination and implementation by MEPA:

1) Developing and enforcing a comprehensive set of environmental regulations relating to: air, water and land pollution; disopsal or solid, liquid and gaseous waste; use and disposal of all chemical, pesticide and radioactive materials; and control of pollution to food and drinking water.

2) Establishing and implementing a system of environmental impact assessments in all projects undertaken by government agencies. 
3) Enhancing the technical capabilities to monitor and analyze information necessary to anticipate environmental damage and take preventive measures.

4) Maintaining and updating a permanent iriventory of the Kingdom's environmental resources, key eco-systems and wildlife.

5) Reducing the adverse environmental impacts of transportation, especially in highly populated areas, through the enforcement of emission standards for vehicles, the encouragement of fuel efficiency and the use of lead-free fuel, and improved traffic management and urban planning programs.

6) Adopting national plans for the use of agricultural land, pastures, forests and water resources, with due regard to the conservation of these resources for use by future generations and prevention of their degredation.

7) Adopting appropriate measures to carry out the required liasion among the different agencies involved with environmental issues and protection, and to enhance MEPA's role and mandate in this regard.

8) Cooperating closely with other environment-related organizations, both within the GCC countries and internationally.

The Fifth National Development Plan (1990-1995) identified six key environmental issues. These are: Environmental Standards, Environmental Impact Assessments, Environmental Awareness, Enforcement of Environmental Regulations, Environmental Monitoring and Coordination of Environmental Activities.

The participatory role of the private sector in environmental work was promoted by Section 15.4.3. of the government's Fifth Development Plan 
(MOP, 1990, p. 393). According to the Plan, the private sector can play an important role in protecting the environment in three ways, the third of which was stated as follows:

There are many potential commercial benefits from sponsoring environmental conservation projects. Throughout the world, corporations are learning that their images are enhanced through their support of environmental efforts, and damaged by a lack of responsibility towards the environment. In this regard, the establishment of effective channels for private support of environmental efforts (such as non-profit organizations or foundations) would be an important private sector initiative.

C) Environmental protaction standards. In accordance with its charter, MEPA issued an initial set of standards on $1 / 11 / 1402 H(20 / 8 / 1982$ AD). The document includes source and ambient standards designed to protect air and water quality by limiting the emission of pollutants from sources and the concentration of pollutants in air and water. The standards apply to all existing and planned facilities, both public and private, including industrial projects, transportation facilities, commercial and agricultural activities, sewage treatment plants, and human settlements within the Kingdom. The standards document permits MEPA to make exceptions by granting variances under special circumstances.

There is evidence that some of the standards are considerably less stringent than the United States national standards, such as the Ozone National Standard of $0.12 \mathrm{ppm}$ (parts per million) no more than once per year (letter of the chief of the San Francisco Bay Area Air Quality Management District to the MEPA, 25/1/1983). The MEPA national standard is $0.15 \mathrm{ppm}$ no more than twice in one month (30 days). 
Another problem is that some of the standards established by MEPA and other agencies are based primarily on studies of temperate organisms. Consequently, the adequacy of the standards needs to be verified by performing studies on native organisms under conditions that suitably model the rigors of the Saudi environment (SRI, 1984, p. IV-100).

MEPA does not have direct auth:ority to enforce the standards. The standards document provides that MEPA enforces the environmental protection standards through its mandatory review authority. MEPA certifies the acceptability of proposed new facilities or major modifications to existing ones. This certification is provided to the licensing authority (for example, the Ministry of Industry and Electricity for industrial projects) (SRI, 1984).

Many additional standards and guidelines are required to address important existing and potential environmental problems. The standards document did not address noise pollution, solid waste disposal, soil pollution, motor vehicle emissions, drinking water quality, toxic and hazardous substances, radiation and radioactive waste. Although some of these standards had been drafted by MEPA or other governmental organizations, they are not approved yet.

d) National Environmental Policy Law. The functioning of a national law is imperative because it will cater to unity of purpose, allow for distribution of duties and responsibilities and make coordination relatively easier (AbdAllah, 1985). The heads of the Gulf Cooperation Council States decided during their sixth summit (1985) to approve thirteen Basic Policies and Principles for Environmental Protection in the GCC States, which included item two: the preparation of a comprehensive environmental policy by each State. MEPA, in collaboration with IUCN's Centre for Environmental Policy, Legislation and 
Administration (Bonn, Federal Republic of Germany) has drafted a National Environmental Policy (MEPA, 1989). This policy had been under review by relevant governmental organizations for many years, and therefore it does not officially exist yet. The main features of this instrument are:

--General Principles

--Scope

--Definitions

--General obligations of authorities

--Duties of personnel

--Contingency measures

--Use of best available technology

--Environmental monitoring

--Environmental assessment of new projects

--Land use planning

--Conservation of natural resources

--Environmental awareness and education

--Obligations of lending authorities

--Functions and responsibilities of the central environmental agencies

e) Environmental Impact Assessment. In accordance with the 1985

decisions of the sixth summit of the heads of the GCC states, environmental impact assessment is to become an integral part of feasibility studies for all programs and projects. MEPA has prepared a draft Environmental Impact Assessment Policy which includes procedures and guidelines to be followed for all projects and programs (NCE, 1992). However, it had been at the draft stage for many years.

f) National Conservation Strategy. MEPA has also drafted a National Conservation Strategy for consideration by all concerned authorities. This is consistent with the document entitled $A$ World Conservation Strategy prepared by the International Union for Conservation of Nature and Natural Resources (IUCN), in cooperation with the United Nations Environment Program (UNEP) 
and the World Wildlife Fund (WWF) (MEPA, 1989). The contents of this policy include:

--The need for a conservation strategy

--Regional commitments

--Strategic principles

--Conservation principles for the Kingdom

--Goals

--Powers and responsibilities

--Conservation of natural resources

--Incorporation of environmental considerations in government decisionmaking

--Environmental education

--Control of environmental contamination

g) Royal and Executive Decrees and Orders. These Royal and Executive decrees and orders are the highest legal instruments in the Kingdom.

--Royal Decree No. M/22 on ( $3 / 5 / 1398 \mathrm{H})$ issued the forests and rangeland policy.

--Royal Decree $M / 26$ on $(25 / 5 / 1398 \mathrm{H})$ issued the birds and wildlife hunting policy.

--Royal Order 1182 / 8 on (5 / 7/1405 H) bans ownership of forest lands and their exploitation.

--Council of Ministers Decree No. 157 on $(20 / 11 / 1411$ H) issued the national oil pollution contingency plan.

--Royal Decree No. 7 / M / 8903 on $(21$ / 4/1401 H) assigned to the Meteorology agency national environmental protection responsibilities.

--Royal Decree No. M / 22 on (12/9/1406 H) created and issued the policy of the National Commission for Wildlife Conservation. and Development.

-Royal Decree M / 27 on (24 / 6 / 1394 H) issued the policy on seaports and lighthouses.

--Council of Ministers Decree No. 1840 on (10/11/1396 H) concerned the annual tree planting (arbor) week.

--Council of Ministers Decree No. 1054 on (7/9/1393 H) concerned establishments causing disturbances, harm or danger to the public.

--Council of Ministers Decrees No. 207 and 208 on (26/1/ 1396 H) issued the agricultural and veterinary quarantine policies.

--Council of Ministers Decree No. 271 on $(23 / 11 / 1404 \mathrm{H})$ obligated certain industries to use the best available technology to reduce pollutant emissions. In addition, it requires that environmental 
factors and implications must be considered in site selection of industrial facilities, residential communities and other pollution sources.

--Royal Decree No. $M / 21$ on $(6 / 9 / 1389 \mathrm{H})$ issued the labor and laborers policy. This policy includes a section on occupational health and safety.

--Council of Ministers Decree No. 19 on $(10 / 1 / 1396 \mathrm{H})$ issued guidelines for trade in agricultural pesticides.

--Council of Ministers Decree No. 25 on (29 2/1409 H) issued approval of the guidelines for municipal fines and sanctions.

--Council of Ministers Decree No. 877 on $(21 / 11 / 1389$ H) approved the occupational diseases list.

--Royal Decree No. M / 34 on $(24 / 8 / 1400 \mathrm{H})$ addressed the conservation of water resources.

\section{Regional Policies and Agreements}

Because Saudi Arabia has extensive borders with many countries and with both the Red Sea and the Arabian Gulf, regional agreements concerning the protection of the environment are of great importance. They are as follows:

a) Kuwait Action Plan. In 1978, the Kuwait Regional Conference of Plenipotentiaries on the Protection and Development of the Marine Environment and the Coastal areas was held. Eight states--Bahrain, Iran, Iraq, Kuwait, Oman, Qatar, Saudi Arabia and the United Arab Emirates adopted the Kuwait Action Plan, the Kuwait Regional Convention For Cooperation On the Protection Of the Marine Environment From Pollution and the Protocol Concerning Regional Cooperation in Combatting Pollution By Oil and Other Harmful Substances in Cases of Emergency. The Convention provides for the establishment of a Regional Organization for the Protection of the Marine Environment (ROPME). This was established in Kuwait in 1981. The accession 
of the Kingdom to the agreement was ratified by Royal Decree $M / 42$ on 29/11/1401 H, corresponding to September 27, 1981.

b) Red Sea and Gulf of Aden Environment Programme. The Kingdom of Saudi Arabia is a signatory to the Regional Convention for the Conservation of the Red Sea and Gulf of Aden Environment, and the Protocol Concerning Regional Cooperation in Combatting Pollution By Oil and Other Harmful Substances in Cases of Emergency, and the Action Plan. Royal Decree M/51 on $3 / 9 / 1405 \mathrm{H}$ ratified this convention. The Red Sea and Gulf of Aden Environment Programme (PERSGA) was established in Jeddah, Saudi Arabia.

c) Saudi-Sudanese Joint Red Sea Commission. This was established in $1975(1395 \mathrm{H})$ with the signing of a bilateral agreement between the two governments. Its purpose is to organize and supervise research and development work required to exploit the metal-rich sediments of the Red Sea. The commission has an environmental programme that monitors the impacts of exploitation on marine life and the coastal environment (SRI, 1984, MEPA, 1989).

d) The Gulf Cooperation Council. On 19-20 Safar, 1407 H (October 22-23, 1986), the Heads of State of the GCC signed a document entitled Policies and General Principles for Environmental Protection. This agreement, which consists of 13 articles, binds the Kingdom in terms of a number of responsibilities. Three of its major points are: 1) the states will establish comprehensive law for environmental protection; 2) legislative and coordinating organizations within each state are to be established, enhanced and supported; 3) environmental impact assessment procedures are to be adopted. 
The author of this thesis had the honor of serving on loan for four years at the Secretariat General of the Gulf Cooperation Council in Al-Riyadh, Saudi Arabia, from 1985 to 1989 . During four years of coordinating environmental work in the six Gulf States, several studies were conducted, the recommendations of which were adopted by the ministers responsible for the environment in the GCC states and became regional policies. These include: 1) a national policy to produce and use lead-free gasoline and low-sulfur fuels; 2) a national chemical safety policy; 3) a national solid waste recycling policy; and 4) a national used motor oil recycling policy.

e) The Arab Council of Ministers of the Environment. On 12 Safar, $1407 \mathrm{H}$ (October 14, 1986), in Tunisia, the Arab League adopted the Arab Declaration on Environment and Development. It is, in principle, similar to the GCC decisions, reinforcing the need for institutionalization in a numijer of important areas.

All the measures outlined above have taken place as a deliberate process in implementing a conservation strategy at the Regional level, which the Kingdon of Saudi Arabia has spearheaded since 1984, and was initiated even before the World Conservation Strategy was launched (Al-Gain, 1989).

\section{Internaiional Agreements}

The following is a list of international agreements signed by Saudi Arabia and officially ratified (MCE, 1992):

1) the International Convention for the Prevention of Pollution of the Sea by oil (1954) 
2) amendments to the International Convention for the Prevention of Pollution of the Sea by oil (1954), concerning tank arrangements and limitation of tank size

3) amendments to the International Convention for the Prevention of Pollution of the Sea by cil, concerning the protection of the Great Barrier Reef

4) Agreement for the Establishment of a Commission for Controlling the Desert Locust in the Near East (1964)

5) Treaty of Principles governing the activities of States in the Exploration and Use of Outer Space, including the moon and other celestial bodies (1967)

6) Treaty on the Prohibition of the Emplacement of Nuclear Weapons of mass destruction on the seabed and on the ocean floor and in the subsoil thereof (1971)

7) Convention on the Prohibition of the development, production and stockpiling of Bacteriological (Biological) and Toxic Weapons, and on their destruction (1972)

8) Convention concerning the Protection of the World Cultural and Natural Heritage (1972)

9) United Nations Convention on the Law of the Sea (1982)

10) Convention on early notification of a Nuclear Accident (1986)

11) Convention on assistance in the case of a Nuclear Accident or Radiological Emergency (1986)

12) Basel Convention on the control of transboundary movements of Hazardous Wastes and their disposal (1989)

13) Treaty on Preservation of migratory species of wild animals, Royal Decree No. M / 27 on (26/11/1990)

14) The International Salvation Convention ratified by the Royal Decree No. M / 23 on $(29 / 10 / 1411$ H) 
There are also at least 15 other treaties which are being considered by the Saudi Arabian Government. This list includes the 1973 Convention on International Trade in Endangered Species of wild fauna and flora (CITES) (MCE, 1992).

\section{Governmental Environmental Organizations}

Waldo defined an organization as "the structure of authoritative and habitual personal interrelations in an administrative system" (1955, p. 6). Chester Barnard wrote about the theory of formal organization that "an organization comes into being when (1) there are persons able to communicate with each other (2) who are willing to contribute action (3) to accomplish a common purpose" (1980, p. 82). He continues, "for the continued existence of an organization, either effectiveness or efficiency is necessary; the longer the life, the more necessary both are." In applying these concepts to organizations concerned with the administration of the environment in Saudi Arabia, it is readily evident that such organizations exist, but the degree of their effectiveness and/or efficiency is not. The success of any organization is essentially measured by its ability to fulfill its goals. This section will attempt to describe the exclusive environmental organizations in an attempt to delineate the extent of their success in fulfilling their objectives.

Meteorology and Environmental Protection Administration. MEPA was created on 21 / 4 / $1401 \mathrm{H}$ (1981) by Royal Decree No. 7 / M / 8903 from the General Directorate of Meteorology as the focal point for organizing and coordinating environmental protection activities in the Kingdom of Saudi Arabia. These 
protection activities are to be directed at enhancing the health, safety and welfare of the people and to promote their overall economic and social wellbeing. MEPA's added functions are to conduct environmental surveys, recommend regulations and other measures, assess levels of environmental pollution, stay abreast of regional and international developments in environmental protection, and establish standards and specifications for pollution control to be considered by the appropriate authorities when issuing permits for industrial and agricultural projects.

Under MEPA's charter the Environmental Protection General Directorate (EPGD) was established as the entity responsible for environmental protection affairs. Its functions include the following: 1) recommending environmental quality and source standards and necessary procedures for their implementation; 2) submitting reports on environmental impacts of major projects in the Kingdom; 3) providing assistance and technical advice to industrial and agricultural activities to help comply with standards; 4) submitting reports on the state of the environment and following up on the application of standards and their effects.

The charter also establishes a National Meteorological and Environmental Centre (NMEC) charged with the responsibility of preparing and issuing climatological, environmental and meteorological analyses, forecasts, bulletins and reports in a form conforming with user requirements, including warning and bulletins on the local, regional and international levels.

Gulick stated that, "It has been observed by authorities in many fields that the efficiency of a group working together is directly related to the homogeneity of the work they are performing, of the processes they are utilizing, and of the 
purposes which actuate them. From top to bottom, the group must be unified. It must work together" (1987). In MEPA's case, the first problem is this: MEPA is linked to the Ministry of Defence and Aviation under civil aviation affairs. One might argue that weather service is homogenous with aviation, but environmental protection service is generally not so regarded. The second problem is MEPA's two primary mandates: weather and environmenta! protection services. They are not homogenous, and have different process and purpose.

NMEC, the National Meteorological and Environmental Centre, and EPGD, the Environmental Protection General Directorate, have some overlap in their work, namely, environmental work. Herbert Simon argues that a description of administrative organizations in terms almost exclusively of functions and lines of authority is completely inadequate for purposes of administrative analysis. He also says that a clearly defined description of administrative situations, tasks and organizational influence is necessary (1987). It follows, then, that the assignments of the different divisions of MEPA must be clearly and precisely described.

MEPA operates 28 manned meteorological stations in the airports of the Kingdom, and those are managed by five regional managers. EPGD does not have any local or regional offices outside MEPA's headquarters (this is clearly an operational problem). Daniel Katz and Robert Kahn, in their famous article "Organizations and the Systems Concept, ${ }^{n}$ explained that organizations are a special class of open systems, and share some properties with all other open systems. These include the importation of energy from the environment, the transformation of the imported energy into some product form which is 
characteristic of the system, the exporting of that product into the environment, and the reenergizing of the system from sources in the environment. Open systems also share the characteristics of negative entropy, feedback, homeostasis, differentiation and equifinality. The law of negative entropy states that systems survive and maintain their characteristic internal order only so long as they import from the environment more energy than they expend in the process of transformation and exportation. The feedback principle has to do with information input, which is a special kind of energic importation, a kind of signal to the system about environmental conditions and about the functioning of the system in relation to its environment (Katz \& Kahn, 1987). In applying this concept to MEPA's situation, one can point out that, in order to be effective or even survive, MAEPÂ needis to establish better communication and coordination mechanisms with other organizations; it must establish an environmental monitoring network throughout the Kingdom for data and information collection. On the other hand, MEPA should welcome any feedback from and dialogue with governmental or non-governmental organizations, and citizens concerned with the environment.

Coordination as a function of public administration is a chronic problem in Saudi Arabia (Sa'aty, 1985). MEPA, being the focal point for environmental affairs, must develop more effective mechanisms to coordinate environmental affairs. Addressing the issue of coordination, the Saudi Fifth Development Plan stated:

The activities of many governmental ministries have direct or indirect effects on the quality of the environment, including the Ministries of Agriculture and Water, Defense and Aviation, Municipal and Rural Affairs, Petroleum and Mineral Resources, Industry and Electricity, Interior, Health, 
Transportation, Commerce and Planning; other public sector agencies include the Ports Authority, the Standards Organization ... There is a lack of coordination between MEPA and these other decision-making bodies involved in the planning and implementation of environmental work. Positive steps should, therefore, be taken to remove these obstacles and to enhance cooperation among relevant agencies. (MOP, 1990, p. 393)

Environmental Protection Coordination Committee. EPCCOM was created during $1401 \mathrm{H}$ (1981) as a permanent body to coordinate the work of the various ministries and other governmental units involved in environmental affairs and pollution control. The Chairman of EPCCOM is H.R.H. the Second Deputy Prime Minister and Minister for Defence and Aviation and Inspector General. EPCCOM's membership includes high-level representatives from the following Ministries: Interior, Petroleum and Mineral Resources, Industry and Electricity, Health, Planning, Agriculture and Water, Municipal and Rural Affairs, and Transportation. In addition, it includes the Seaports Authority, King AbdalAziz City for Science and Technology, the National Commission for Wildlife Conservation and Development, the Saudi Standardization and Metrology Organization, and MEPA, which serves as the secretariat general. After the creation of the Ministerial Commission for the Environment, EPCCOM became its Preparing Committee.

The Ministerial Commission for the Environment. The Ministerial Commission for the Environment was formed by Royal Decree No. 5/B/5635 on (14/4/1410 H), and is chaired by H.R.H. the Second Deputy Prime Minister and Minister of Defence and Aviation and Inspector General. It is the highest institutional authority in the Kingdom for all environmental affairs (MCE, 1992). Of special importance to the Commission is the formulation of National Environmental Policies, and the position of the Kingdom of Saudi Arabia in 
international and regional environmental affairs. The President of MEPA serves as the secretary general of this Commission. Its membership is as follows:

-- H.R.H. the Minister of the Interior

-- H.R.H. the Minister of Foreign Affairs

- H.R.H. the Assistant Minister of Defence and Aviation for Aviation Affairs

-- H.E. the Minister of Petroleum and Mineral Resources

-- H.E. the Minister of Finance and National Economy

-- H.E. the Minister of Industry and Electricity

-- H.E. the Minister of Health

- H.E. the Minister of Planning

-- H.E. the Minister of Agriculture and Water

-- H.E. the Minister of Municipal and Rural Affairs

-- H.E. the President of King AbdalAziz City for Science and Technology

-- H.E. the President of MEPA

The National Commission for Wildlife Conservation and Development. The NCWCD was established by Royal Decree M/22 on 12/9/1406 H (May 12, 1986), which was based on the Council of Ministers Decree No. 177 on 25/8 $1406 \mathrm{H}$. The charter of the Commission stated that its main function is to care for, conserve, protect, and develop terrestrial and marine wildlife in the Kingdom, and to conduct, gather, and apply biological research to assure environmental balance. Most wildlife affairs which were MEPA's responsibility were transferred to the NCWCD after its creation. Item Five of Article Three of the NCWCD charter authorizes it to: "Coordinate with the Meteorology and Environmental Protection Administration, other governmental organizations, scientific institutions, and research centers in the Kingdom to achieve its goals and prevent double efforts in its activities" (Council of Ministers Experts Branch, 1408 , p. 11)

The Commission has a Board of Directors comprising:

-- H.R.H. the Second Deputy Premier, Minister of Defence and Aviation, Inspector General and Chairman of the Ministerial Commission for the 


\section{Environment (President)}

-- H.F.H. the Minister of Interior (member)

-- H.R.H. the Minister of Foreign Affairs (Managing Director)

-- H.R.H. the Amir (Governor) of Asir Province (member)

-- H.E. the Minister of Agriculture and Water (member)

- H.E. the President of King AbdalAziz City for Science and Technology (member)

- H.E. the President of the Meteorology and Environmental Protection Administration (member)

- H.E. the Secretary General of the Commission (member)

Since it was created, the NCWCD has been very active in carrying out its mandates. The Commission has implemented a national protected areas program and designated or proposed more than one hundred protected areas in the Kingdom. Three Wildlife Research Centers are in operation, one in AlThmamah near Al-Riyadh, one about 40 kilometers southwest of Al-Ta'if and the third one in Al-Gasseem. The three centers are concerned with the captive breeding of endangered species, especially oryx, Houbara bustard, ostrich and several species of gazelles. the NCWCD also publishes the Arabian Fauna, an international scientific journal. This is in addition to an extensive public education program through the media, and the holding of several International Conferences on Wildlife Conservation in the Kingdom (NCWCD annual Reports, 1987-1993).

Besides MEPA and MCWCD, there are several other governmental organizations which have one or more environmental functions or responsibilities. These are:

1) The Ministry of Interior. It enforces, civil defense codes, game hunting seasons and investigates environmental crimes.

2) The Ministry of Agriculture and Water. It has a Forest and Rangeland General Directorate, and is also responsible for water and dam projects, pesticide regulations and agricultural projects licenses. 
3) The Ministry of Municipal and Rural Affairs. It has an Environmental Health General Directorate. The municipalities perform sanitation work such as food monitoring, pest control and solid waste management. It is also responsible for city planning.

4) The Ministry of Industry and Electricity has responsibility for licensing and siting of industrial projects.

5) Customs, which inspect imported materials and apply the veterinary and agricultural quarantine rules.

6) King AbdalAziz City for Science and Technology. It has an Institute for Environmental and Natural Resources, which sponsors and funds environmental research.

7) The Ministry of Commerce is responsible for consumer protection and quality assurance.

8) The Saudi Arabian Standards Organization, which has an important role in setting standards for all goods and products.

9) The ivinistry of Health. It has an Environmental Health General Directorate and operates several Quit-Smoking clinics. In addition, it has a nutrition directorate.

10) The Ministry of Planning. It oversees the National Five Year Deveopment Plans.

11) The Royal Commission for Jubail and Yanbu. The industrial cities of Jubail and Yanbu have an intensive environmental program and have won several international awards from UNEP and others.

It is evident from this brief survey that MEPA, the focal point and official environmental organization of the country, is not alone in this responsibility. In fact, it lacks the legal, financial and human resources that most of the other mentioned organizations enjoy.

Unlike NCWCD and all other governmental organizations, MEPA's headquarters are not located in the capital. This contributes to its irresponsiveness due to the delay or even sometimes absence of feedback 
(information input). Also, a significant portion of its budget goes to pay per diem allowances and purchase airline tickets for travel to the capital.

In light of the above, the thesis recommends establishing a Ministry of the Environment, with an organizational chart that includes the Environmental Protection Department of MEPA as its core and as many environmental units of the above-mentioned organizations as practicably possible. This is needed to insure that environmental protection work is done, improve responsiveness, reduce friction and save financial resources. It has been noted that "There is scarcely an important department or ministry in the governments of the technological nations that has not undergone successive organizational change in recent years. In the United States Congress set up in 1967 the Department of Transportation (thus consolidating activities formerly carried out in thirty different agencies)" (Toffler, 1970, p. 130).

This Ministry must be delegated with a comprehensive national environmental law, and have authority to issue and enforce national environmental regulations and standards. It should be located in the capital city of Al-Riyadh, with offices in every region of the Kingdom. 


\section{CHAPTER SIX}

\section{PUBLIC OPINION SURVEY ON ENVIRONMENTAL AFFAIRS IN THE KINGDOM OF SAUDI ARABIA}

This survey was designed to test several hypotheses in addition to providing data concerning public opinion on several environmental problems, issues and governmental organizations that are responsible for serving one or more environmental functions. It gains special significance in that it is probably the first public opinion survey to be conducted on environmental affairs in the Kingdom of Saudi Arabia. It is to be hoped that the results of this survey can support the proposal and recommendations contained in this thesis, increase environmental awareness, and lay the groundwork for future surveys on the same subject.

\section{Methodology and Sample}

A pilot survey questionnaire was first designed and submitted to several professionals for review, including a MEPA senior environmental expert and two faculty members in chemistry and public administration at King Saud 
University in Al-Riyadh. Their constructive comments were incorporated into the the final questionnaire. it was mailed or distributed to a sample population of approximately 350 in several cities in Saudi Arabia. Total response was 220. However, 40 responses were not counted because they arrived after the results had been computed at the Educational Research Center in King Saud University.

The sample population consisted of two main groups, non-specialists and specialists. Due to difficulties and limitations on random sampling in Saudi Arabia, a convenient sample was selected from different age, income, education and status groups. The following is an analysis of the respondent groups.

Age: Two respondents were under 15; 39 were in the 15-30 years category; 96 were in the 31-45 years category; 15 were in the 45-60 category; one was over 60 years; and 16 respondents did not answer this question.

Income: Seventeen had a monthly income less than 3000 Saudi riyals (one Saudi riyal is equivalent to $\$ 3.75$ U.S.); 15 were in the $3000-5999$ riyals category; 49 in the 6000-8999 category; 29 in the 9000-11999 category 29 in the 12000-14999 category; 27 in the over 15000 category; and 14 did not respond.

Education: Four respondents had an elementary education certificate; eight had an intermediate school certificate; 13 had completed high school; 23 had diplomas; 57 held bachelors' degrees from colleges and universities; 29 had been awarded masters' degrees; and 34 respondends held Ph.D. degrees.

Specialization: Forty-seven respondents were identified as specialists by the researcher, and 133 as non-specialists. The first group constituted 
approximately $26 \%$ of the sample population, and the second constituted approximately $74 \%$.

\section{The Questionnaire}

The foilowing is a transiation from the Arabic language of the 25 questions included in the questionnaire:

1. What is the last degree you earned?

$$
\begin{aligned}
& \text { elementary _ intermediate _ocondary _ diploma } \\
& \text { bachelors _ masters _ doctorate _ }
\end{aligned}
$$

2. What is your profession?

3. What was your major field in your education?

4. What is your age?

$$
\text { below } 15 \text { _ } 15 \text { to } 30 \text { _ } 31 \text { to } 45 \text { _ } 46 \text { to } 60 \text { _ above } 60 \text {. }
$$

5. What is your monthly income?

$$
\begin{aligned}
& \text { below } 3000 \text { _ } 3000 \text { to } 5999 \text { _ } 6000 \text { to } 8999 \\
& 9000 \text { to } 11999 \text { _ } 12000 \text { to } 14999 \text { _above } 15000
\end{aligned}
$$

6. What is your understanding of environmental protection? protecting plants and animals only _ protecting plants, animals and humans _ protecting plants, animals, humans, soil and water _ protecting all the constituents of the planet, including natural processes and systemis

7. What is the focal point for environmental protection in the Kingdom of Saudi Arabia?

The National Commission for Wildlife Conservation and Development _ _ The Meteorology and Erivironmental Protection Administration _; The Ministry of Health The Ministry of Municipal and Rural Affairs _; The Ministerial Commission for the Environment

8. What is your assessment of the state of the environment in the 
Kingdom of Saudi Arabia?

the environment is in a dangerous state of pollution and deterioration _ ; there are acute environmental problems which require quick attention _ ; the environment is good but there are normal environmental problems ; the environment is in an excellent state

9. Order the following environmental problems in Saudi Arabia according to their importance and need for treatment:

- air pollution from mobile and stationary sources

- environmental and food contamination from chemicals such as pesticides overgrazing, aggressive wood cutting and desertification

_ global warming

- hazardous industrial materials and waste

- water pollution

- rise of the water table under cities

- sewage problems

- solid waste disposal methods

- increase of environmental diseases such as cancer, hepatitis and kidney failure pollution from used motor oils groundwater depletion holes in the czone layer

- marine pollution from oil and other harmful substances

- deterioration, reduction and extinction of wildlife

- environmental pollution from lead and heavy metals

- radiation pollution

- noise pollution

- waste from hospitals and laboratories

- deterioration, pollution and salinization of agricultural soils

10. The Fifth Development Plan (1990-1995) mentioned that, due to the lack of coordination between MEPA and some other agencies, many obstacles surfaced which hinder the planning and implementation of environmental work. In your opinion, what is/are the most important reason(s) for this?

lack of awareness of the importance of environmental considerations when planning and implementing development, agricultural and industrial projects distance between the headquarters of MEPA and other organizations which deal with the environment lack of sufficient administrative and financial support 
for MEPA and weakness of its authority in enforcing environmental standards and regulations

11. There are many governmental organiztions which are responsible for environmental protection or provide environmental services as part of their functions. In your opinion, what is the degree of activity and effectiveness of the following?

GOVERNMENTAL ORGANIZATION

DEGREE

National Commission for Wildlife Conservation

12345

Meteorology and Environmental Protection Admin. 12345

Ministry of Municipal and Rural Affairs

(environmental health / solid waste /

Fiinistry of Health city planning)

12345

(environmental health / nutrition / medical waste)

12345

Ministry of the Interior

(civil defense / environmental crimes) $\quad 12345$

Ministry of Commerce

(consumer protection / quality assurance)

Water and Sewage Agency

Ministry of Agriculture and Water

(ground water / pesticides / range and forests)

Ministry of Labor and Social Affairs

12345

12345

12345

(philanthropic societies / occupational health)

Ministry of Industry and Electricity

12345

(industrial cities / industrial licenses)

Ministry of Planning

12345

12345

King AbdalAziz City for Science and Technology 12345

Saudi Arabian Standards Organization

12345

12. What is Islam's position on environmental protection?

mandatory upon every person

_ mandatory upon the ruler only 
- mandatory upon the ruler and every person

13. Have you heard about the Saudi Environmental Project?

- yes

- no

14. If the answer is yes, via what medium?

— newspaper

- radio

- television

- friend

- school

- posters and street advertising

15. What is your assessment of the project's activities which have been implemented and/or advertised up to now?

excellent

- the idea is good but the awareness programs need to be re-evaluated

_ don't know

16. The Fith Development Plan (1990-1995) mentioned that the private sector should sponsor environmental conservation projects (such as foundations). Also, the Earth Summit (Brazil, 1992) called on the world to allow non-governmental organizations to play their partnership role. Do you think that the Saudi Environmental Awareness Project which is overseen by MEPA and the Offset Economic Program in cooperation with the private sector is:

a semi-governmental environmental project

- a joint government and private sector philanthropic project a non-governmental organization

- a joint government and private sector commercial project

17. Do you think there is sufficient environmental education and information in the Kingdom of Saudi Arabia?

- yes

- no

18. When you have a question about an environmental element or issue, where do you go to get the answer? 
- an environmental information center

_ a public library

- a university library

- an environmental agency

- Infoterra in Kenya

- other source (specify)

19. There are many individuals and groups which provide environmental information. Please circle the number that represents your confidence level in each one of the following sources:

\section{SOURCE}

Business and industry

Disciplinary and philanthropic societies

Specialized governmental officals

Scientific and technical experts

Oil companies

Environment and law professors

Newspaper editors and correspondents

Judges, scholars and mosque speakers

\section{LEVEL OF CONFIDENCE}

12345

12345

12345

12345

12345

12345

12345

12345

20. Many local, national and international non-governmental organizations in all fields are found in the Kingdom. One model is the philanthropic society, such as the King Faysal Philanthropic Society, the Saudi Society For the Abatement of Smoking, the International Islamic Relief Organization, and others. In addition, some Saudi governmental organizations have joint environmental projects with foreign environmental societies, while many Saudi specialists and scientists joined environmental organizations in other countries in the absence of a Saudi equivalent. Do you support the establishment of a national, regional or international environmental philanthropic society in the Kingdom?

_ I strongly agree

- I agree

- I somewhat agree

- I do not agree

- I strongly disagree 
21. Another model of non-governmental organizations in the Kingdom is the disciplinary society. There are many disciplinary societies in almost all fields, such as the Saudi accounting, engineering, chemical, biological, geographic, historical and archaelogical societies, among others. In addition, there are medical societies in almost all specializations, such as the Saudi Heart, kidney, diabetes and anesthesia societies. These societies are an effective mechanism for the coordination of professional relations and communication among specialists. They conduct studies and research and publish them regularly in a scientific publication. Do you support the establishment of a Saudi Environmental Society?

- no; some existing societies are concerned with the environment, such as the Saudi Biological Society and the Saudi Geographical Society in King Saud University

_ yes; there is a strong need for this society because all existing societies do not specialize in environmental health sciences, pollution control and the effects of pollution on humans and the environment don't know

22. In your opinion, what are the three most important environmental services that these societies can provide?

23. If your answer to questions 20 or 21 is positive, do you wish to participate in the following activities of the proposed society?

- establishing and licensing procedures

- membership in one of its types

_ contributions to support its activities

24. In your opinion, which one of the following is the closest description of the interaction between development activities and environmental and natural resource policies?

- a clash between ideas, philosophies and ideologies about the place and role of mankind in nature a clash of groups or interests (groups of people trying to achieve goals that benefit the interests of their followers)

a clash that depends on national issues and priorities (concerns which change over time, such as 
national economy and defense and food security)

- a clash based on personal goals of those who want

mainly to benefit themselves

25. If you have comments or suggestions, kindly write them on the following page.

Name (optional) Telephone (optional) 


\section{TABLE ONE}

\section{PERCENTAGES OF RESPONSE OPINIONS ON THE SEVERITY OF ENVIRONMENTAL PROBLEMS}

\begin{tabular}{|c|c|c|c|c|}
\hline $\begin{array}{l}\text { The Environmental } \\
\text { Problem }\end{array}$ & $\begin{array}{l}\text { \%of responses } \\
\text { choosing it as \#1 }\end{array}$ & $\begin{array}{l}\% \text { choosing it } \\
\text { within firsi five }\end{array}$ & $\begin{array}{l}\text { \%choosing it } \\
\text { within first ten }\end{array}$ & $\begin{array}{l}\text { \%choosing it } \\
\text { within first } 15\end{array}$ \\
\hline 1) Air pollution & 227 & 57.1 & $\pi 2$ & $\$ 95$ \\
\hline $\begin{array}{l}\text { 2) Chemicals in food } \\
\text { andervironment }\end{array}$ & 182 & 623 & 83.0 & 943 \\
\hline 3) Desertification & 20 & 281 & 549 & 28 \\
\hline 4) Gobal waming & 61 & 204 & 347 & 497 \\
\hline $\begin{array}{l}\text { 5) Hazardous materials } \\
\text { andwaste }\end{array}$ & 3.9 & 276 & 539 & 84.9 \\
\hline 6) Water oollution & 5.8 & 429 & 886 & 88,3 \\
\hline 7) Gound watertogging & 20 & 260 & 553 & 76.7 \\
\hline 8) Sewage & 8.2 & 44.7 & $\pi 4$ & 956 \\
\hline 9) Solid waste & 4.1 & 210 & 568 & 884 \\
\hline 10) Env, diseases & 115 & 38.5 & 583 & 788 \\
\hline 11) Used motor oils & 4.5 & 224 & 54.5 & 846 \\
\hline $\begin{array}{l}\text { 12) Severity of gound } \\
\text { water depletion }\end{array}$ & 200 & 425 & 673 & $\mathbf{3 1 5}$ \\
\hline 13) Ozone depletion & 60 & 148 & 35.6 & 591 \\
\hline 14) Marinepollution & 19 & 234 & 54.5 & 812 \\
\hline 15) Wid dife & 32 & 239 & 510 & 78.1 \\
\hline 16) Lead \& heary metals & 26 & 21.1 & 467 & 717 \\
\hline 17) Baciation & 21 & 116 & 240 & 49.3 \\
\hline 18) Noise & 07 & 107 & 25.5 & 604 \\
\hline 19) Medcal waste & 13 & 9.9 & 377 & 74.2 \\
\hline 20) Soil problems & 1.3 & 18.6 & 50.6 & 80.8 \\
\hline
\end{tabular}




\section{TABLE TWO}

\section{PERCENTAGES AND AVERAGE SCORES OF OPINIONS ON THE EFFECTIVENESS OF ORGANIZATIONS RESPONSIBLE FOR THE ENVIRONMENT}

\begin{tabular}{|c|c|c|c|c|c|c|}
\hline Qnganization. & \% uhectiosene & $\%$ WO & \%thes & $\%$ fxu & $\%$ fixe & Ax _ score \\
\hline NCNCD & 17 & 5.8 & 227 & 459 & 23,3 & 381 \\
\hline MPPA & 4.4 & 16.9 & 356 & 287 & 14.4 & 3,32 \\
\hline $\begin{array}{l}\text { Min. of Muni. } \\
\text { \& Rural Affairs }\end{array}$ & 56 & 222 & 41.4 & 26.5 & 4,3 & 302 \\
\hline Min of Health & 43 & 264 & 442 & 178 & 74 & 298 \\
\hline Min. of Interior & 30 & 24.4 & 429 & 160 & 7.7 & 289 \\
\hline $\begin{array}{l}\text { Min. of Com- } \\
\text { merce }\end{array}$ & 190 & 39.5 & 291 & 120 & 6.3 & 253 \\
\hline $\begin{array}{l}\text { Sewage \& Water } \\
\text { Agency }\end{array}$ & 123 & 337 & 380 & 117 & 4.3 & 262 \\
\hline $\begin{array}{l}\text { Min. of Agricu- } \\
\text { ture \& Water }\end{array}$ & 102 & 39.5 & 363 & 82 & 5.1 & 259 \\
\hline $\begin{array}{l}\text { Min. of Labor } \\
\text { \& Soc. Affais }\end{array}$ & 16.2 & 370 & 29.9 & 136 & 32 & 251 \\
\hline $\begin{array}{l}\text { Min. of Indus- } \\
\text { Sx \& Elecit }\end{array}$ & 90 & 252 & 387 & 21.9 & 52 & 289 \\
\hline $\begin{array}{l}\text { Min. of Plan- } \\
\text { nine }\end{array}$ & 212 & 288 & 342 & 116 & 4.1 & 249 \\
\hline $\begin{array}{l}\text { King AbdalAziz } \\
\text { City for Sci. } \\
\text { \& Techndogy }\end{array}$ & 9.3 & 200 & 293 & 320 & 9.3 & 3.12 \\
\hline $\begin{array}{l}\text { Saudi Stan- } \\
\text { dards Org. }\end{array}$ & 3.2 & 27.3 & 35.7 & 26.6 & 7.1 & 3.07 \\
\hline
\end{tabular}


The Hypotheses and the Findings of the Study

Hypothesis Onę: Public opinion on environmental issues in Saudi Arabia is formed and there is strong support for environmental protection. This hypothesis was tested by questions $6,9,12$ and 24 and was generally confirmed.

Question 6 asked respondents what the term "environmental protection" meant to them. One hundred and thirty-six $(\mathbf{7 7 . 7 \%})$ chose the most correct and comprehensive answer: "the protection of all the planet's constituents, including natural processes and systems." Another 18.9\% (33 respondents) selected "protecting plants, animals, humans, soil, and water," which is the second most comprehensive answer. These two selections represented $96.6 \%$ of all responses, which is evidence that the population holds a comprehensive view oi the environment. In analyzing the responses further, we find that $89.4 \%$ of the specialists selected the most correct answer; compared to $73.4 \%$ of the non-specialists. This difference can be explained by the specialization advantage.

Question 9 asks the respondent to list the 20 listed environmental problems according to their priority. The five most frequently selected as number one are (from high to low): air pollution, groundwater depletion, chemicals in food and the environment, the increase in environmental diseases, and sewage, respectively. The percentages of respondents who ranked each of these as number one are, in the same order: $22.7 \%, 20.9 \%, 18.2 \%, 11.5 \%$, and $8.2 \%$. These environmental problems represent five of the most visible and serious in the Kingdom. When environmental problems were ranked according 
to their frequency of selection among the top five, it was found that the most frequently selected is that of chemicals in food and the environment $(62.3 \%)$, followed by air pollution $(57.1 \%)$, sewage $(44.7 \%)$, water pollution $(42.9 \%)$ and groundwater depletion (42.5\%). An interesting finding is the ranking of both global warming and ozone depletion, which were ranked as number one by only $6.1 \%$ and $6 \%$, respectively; they were placed among the rop ten environmental problems by only $34.7 \%$ and $35 \%$ of the respondents, respectively. This shows the low importance of these problems to the Saudi public in comparison with other local problems. Another possibility is that public opinion does not give significance to these problems because they remain unproven at any degree of certainty by the scientific community despite loud rhetoric by some outside scientists and politiclans. Table One contains a complete tabulation of this question.

Question 12 asks the knowledge of the respondents about the rule of Islam on protecting the environment. Of those who answered this question, $79.6 \%$ thought that it was mandatory upon the government and every individual to do so. One respondent $(0.6 \%)$ thought it is the duty of the government alone to protect the environment, while $33(19.8 \%)$ said it was the duty of every individual. This indicates that $99.4 \%$ of respondents thought it is the religious duty of every individual to protect the environment.

Question 24 asks the respondents to identify the reason for the clash between developmental activities and envisonmental policies. About $73 \%$ of all respondents chose an answer to this question, while $27 \%$ did not answer and a few responded with an objection note. This means that $73 \%$ of the public believe that there are environmental problems associated with developmental 
activities in the Kingdom. In addition, $46.6 \%$ of those who answered this question said that national priorities, such as food security, are the most probable reason for this clash. Only $20.6 \%$ indicated that the clash is due to differing ideas and philosophies about the place and role of mankind in nature. Seven percent said that the clash is a result of group interests, and $26 \%$ said it is due to personal goals.

Hypothesis Two: The national focal point for environmental protection in the Kingdom of Saudi Arabia has coordination problems.

This was tester. with questions 7 and 10 and was confirmed. Question 7 asks the respondents, "What is the national focal point for environmental protection?" Since there is only one correct answer, those who chose more than one answer were considered wrong. It was found that only $49 \%$ of respondents knew that MEPA, the Meteorology and Environmental Protection Administration, is the national focal point. Another, more suprising fact is that only $54 \%$ of the environmental specialists knew the correct answer, while $60 \%$ of the non-specialists checked it. This is partly due to the fact that the specialists' group had the majority of multiple answers, which is a function of the fact that many governmental organizations do not recognize MEPA as the only focal point for environmental affairs. This was indicated by several statements in the questionnaire itself, and during contacts. However, it must be concluded that less than $50 \%$ of the population identified the governmental organization responsible for coordinating all environmental activities in the country.

Question 10 asks for the reason(s) why MEPA has a weak coordination function, as per the testimony of the Fifth National Development Plan. The responses are as follows. The first reason, which is the low awareness level of 
the importance of environmental planning, was chosen by $47.2 \%$ of respondents; 3.4\% chose the distance between the headquarters of MEPA and other organizations as the reason for the problem; $20.8 \%$ said that the insufficient financial and political support of MEPA is the reason for coordination problems. Finally, $37.1 \%$ thought all three were reasons. This clearly shows that the public believes that environmental awareness among governmental officials is the main reason for the weak coordination between MEPA and other organizations. However, it is MEPA's responsibility to produce environmental education and information programs designed both for citizens and officials. The finding that fewer than half the respondents knew that MEPA is the national environmental focal point is proof of this needed effort by MEPA. Another conclusion is that the physical location of MEPA's headquarters is probably unknown to many pecple. This is evidenced in the low response rate. It is the opinion of many governmental officials and the author of this thesis that MEPA's geographical location is causing serious communication and coordination problems. These problems are addressed further in Chapter Five.

Hypothesis Three: The Saudi public wants improvements in the environmental services delivered by some governmental organizations. This was tested by questions 8,11 and 17 and was generally confirmed.

Question 8 asks, "What is your assessment of the state of the environment in the Kingdom?" The result indicates that the majority of respondents $(60.3 \%)$ thought that the environment was generally in a good state, with some ordinary environmental problems; $34.6 \%$ said that there were acute environmental problems, which require quick action; $1.7 \%$ indicated that they thought the environment was dangerously polluted and deteriorated; and $3.4 \%$ checked 
"the enviroment is in an excellent state." This finding shows that approximately one in three respondents believed there are serious environmental problems that it is urgent to solve. An interesting finding is that the percentages of respondents who held this opinion are the same for both the specialist and the non-specialist groups; these were $34 \%$ and $34 . \%$, respectively.

Question 11 aims to find out public opinion (on a scale from 1.00 to 5.00 ) on the degree of activity and effectiveness of some organizations that are responsible for the environment, or provide some environmental services. The analysis showed that the National Commission For Wildlife Coniservation and Development had the highest average score, while the Ministry of Planning had the lowest average score. The results are compiled in Table Two. Analysis of the numbers showed that eight of the 13 organizations listed had a mean score of less than 3.00 (which is mediocre or satisfactory). The other five organizations had a mean score between 3.00 and 4.00 , but none had a score higher than 4.00 (good performance). The results compiled here are not conclusive because they depend on personal experiences and backgrounds, and also on the effectiveness of the public relations department in each organization. Therefore, these data should be considered exploratory. Nevertheless, the results give a general perspective on public opinion and demands. For example, the Ministry of Agriculture and Water had the lowest combined percentage of responses in the good (4) and excellent (5) columns, which was only $14 \%$ of respondents. The fact that $86 \%$ of respondents said they thought that the MOAW is doing a mediocre or poor job on environmental issues is a reflection of public opinion on issues such as water depletion by agriculture and the excessive and unsupervised use of pesticides, which are 
under the jurisdiction of the MOAW. This finding is supported by the large amount of press coverage on these two issues. At the same time the National Commission for Wildlife Conservation and Development (NCWCD), which enjoys strong political support and has an extensive public relations program, had a combined percentage of $69.2 \%$ of respondents who said the Commission was doing a good or excellent job.

Question 17 asks the respondents, "Do you think there is sufficient environmental education and awareness in the Kingdom?" One hundred and forty-eight out of 165 respondents to this question said no, that they did not "think there is sufficient environmental education and awareness. Only seventeen respondents (10.3\%) said yes.

Hypothesis Four: There is strong support for establishing non-governmental environmental societies in Saudi Arabia, as this is compatible with the political and cultural systems of the Kingdom. This was tested with questions 20, 21, 22 and 23, and was strongly confirmed.

Question 20 asks, "Do you support establishing a national, regional or international philanthropic (non-profit) environmental protection society in the Kingdom of Saudi Arabia?" The results are as follows. Eighty-two respondents of a total of 171 (48\%) said, "I strongly agree." Sixty-two respondents (36.3\%) said, "I agree." Sixteen (9.4\%) said, "I agree to a certain extent." Eight persons $(4.7 \%)$ said, "I do not agree," and only three respondents (1.8\%) strongly disagreed. It was found that the higher the age and income levels of respondents were, the stronger was their support for this society. Another finding is that the percentages of those specialists and non-specialists who 
either "strongly agree" or "agree" to this proposal are approximately equal. These are $84.4 \%$ and $84.0 \%$, respectively.

Question 21 asks, "Do you support a proposal to establish a disciplinary Saudi Environmental Protection Society?" The respondents who agree were $142(85.5 \%)$ and those who did not agree were nine (5.4\%). Fifteen respondents (9\%) did not have an opinion. It was found that the higher a respondent's age was, the more likely it was that that person gave his or her support. However, when analyzing support levels for this society in relation to income, it was found that support is relatively uniform in all income groups. It was also found that support for this type of society is higher among the specialists group. The percentage of specialists voting yes was $91.1 \%$, while $83.5 \%$ of the non-specialists said yes. Those who did not have an opinion were $10.7 \%$ in the non-specialists group, but only $4.4 \%$ among the specialists group.

Question 22 asks what three services can be provided by the proposed society or societies. There were many different responses to this question. The most prominent among these are: 1) environmental education and information, 2) environmental studies and research, and 3) environmental pollution control. Other responses include working with (and some even said watching) governmental agencies responsible for the environment and coordination with other societies outside Saudi Arabia.

Question 23 asks the supporting respondents if they wish to participate in the proposed society. Among this group, 11.1\% chose the establishing and licensing activity, while another $11.1 \%$ chose to give contributions. The remaining $77.8 \%$ said they wish to be members of this society when it is established. 
Hypethesis_Five: The Saudi Environmental Awareness Project (SEAP) has been successful in its first year in increasing awareness with useful programs, and it has been accepted by the public as a non-governmental initiative. This was tested via questions $15,16,17,18$ and 19 and was not generally supported.

Question 15 asks, "What is your assessment of the SEAP activities that are implemented so far?" The results are that $9.8 \%$ of respondents said it was excellent, $53.0 \%$ said the awareness programs need to be reassessed, and $37.2 \%$ answered "unknown." This result shows that more than $90 \%$ of respondents either were not informed of the project's programs or knew but did not approve of them.

Via Question 16 it was found that $60.3 \%$ of respondents believed that the SEAP is a semi-governmental project, while only $26.0 \%$ said it was a joint philanthropic project; $4.8 \%$ said it was a non-governmental organization, and $8.9 \%$ said it was a joint commercial project between the government and the private sector.

As was found previously from responses to Question $17,89.7 \%$ of respondents said that there are not sufficient environmental awareness efforts in the Kingdom.

In response to Question 18,24.3\% said they would go to an environmental information center to obtain environmental information, while only $9.9 \%$ and $7.2 \%$ chose to go to a public library or a university library, respectively; $37.5 \%$ chose to go to an environmental organization. The finding that respondents are three times more likely to go to an environmental information center than to a university or public library should tell SEAP officials, and environmental 
organizations, governmental and non-governmental, that an environmental information center is needed. None exists at this time in the Kingdom of Saudi Arabia.

Question 19 asks for respondents' levels of confidence (on a scale from 1.00 to 5.00 ) to be indicated in the environmental information provided by some groups. Among these groups, that of businessmen scored the lowest; their average was 2.15. Other groups scored as follows: (existing) nongovernmental organizations, 2.90; environmental officials, 3.22; science and technical experts, 3.95; oil companies, 3.10; law and environmental science professors, 3..0; newspaper editors and correspondents, 2.53; judges and mosque speakers, 2.87. These numbers indicate that the public holds the highest confidence in technical experts and environmental scientists, but that the lowest is in businessmen. 


\section{CHAPTER SEVEN}

\section{CONCLUSIONS AND RECOMMENDATIONS}

Non-governmental environmental organizations have gained more stature since the United Nations Conference on Environment and Development (Brazil, 1992). Chapter 27 of Agenda 21, entitled "Strengthening the role of non-governmental organizations: partners for sustainable development," calls on society, governments and international bodies to develop mechanisms to allow non-governmental organizations to play their partnership roles responsibly and effectively in the process of environmentally sound and sustainable development. The Kingdom of Saudi Arabia, a founding member of the United Nations system, has licensed and supported, both financially and administratively, more than one hundred non-governmental organizations (philanthropic and discliplinary and cooperative). These do not include an environmental protection society as of yet.

This thesis seeks to explore the cultural and political foundations of and areas of need for non-governmental environmental protection work in the Kingdom of Saudi Arabia. Islam, the official religion of the people and government of the Kingdom, provides general and specific mandates and principles for citizen participation in the protection of the environment--in fact, all governmental affairs. The Saudi government, operating according to Islamic 
teachings, has allowed some forms of citizen participation, such as access to political leadership, writing critical environmental articles for the press, and allowed foreign non-governmental environmental organizations, such as IUCN, Greenpeace and others, to participate in environmental work in the Kingdom.

During 1993 a group of businessmen agreed to participate with MEPA, the Meteorology and Environmental Protection Administration, and the Offset economic project, which is a group of several international companies working with the government of Saudi Arabia under the umbrella of the Ministry of Defence and Aviation. The resultant joint effort, the Saudi Environmental Awareness project, is an unprecedented step in the history of the Kingdom in environmental responsiveness and management. However, this project does not qualify to be labelled a "philanthropic society" or a "non-governmental organization," and more importantly, it has not yet produced long-term environmental education and awareness programs. These conclusions are supported by the results of the survey contained in this thesis.

Environmental issues in the Kingdom are becoming more problematic and some even threaten not only the well-being of the Saudi people, but the very lives of future generations. An example is the threat of groundwater depletion and the noticeable rise in environmental diseases in recent years, such as cancer, which is linked mainly to the sharp increase in the use of pesticides, kidney diseases, diabetes and hepatitis.

This thesis offers a proposal for the establishment of the first nongovernmental environmental society in the Kingdom of Saudi Arabia. An important part and service of the proposed environmental society is an environmental information and education center. This center can provide a 
data base for chemicals used in agriculture, such as pesticides; food additives, such as preservatives and coloring agents; and other chemicals used by households.

Solid and hazardous waste is increasingly becoming a major environmental problem in the Kingdom. A comprehensive recycling and source reduction program is crucial for the sustainable development of any nation, because when garbage is thrown away in solid waste dumps, resources are taken out of the natural cycle forever, and new, non-renewable raw resources are extracted. Another important service that can be provided by the environmental information center, therefore, is to educate the public about the importance of waste reduction and recycling. The center can provide information about solid waste generation, regulations, and recycling technologies and opportunities in the Kingdom and other countries. In short, an environmental information center is needed to provide people with a resource base from which to answer their environmental questions and also to prepare and conduct some educational programs to teach people how to care for their local environment and to conserve natural resources.

Governmental organizations responsible for the environment, especially MEPA as the national focal point, have had difficulties in the coordination of environmental affairs. Also, they have been unable thus far to effectively cooperate with each other. The proposed society can heip improve the coordination process in more than one way. One is that the society will provide a platform for all environmental officia!'s and specialists to communicate with one another via seminars and conferences and through an environmental journal and other publications. 
It is the recommendation of this thesis that the government of the Custodian of the two Holy Mosques King Fand Bin AbdalAziz, in accordance with her international commitments and current administrative policies, such as the National Development Plan and the Basic Government Policy, issue a policy for citizen environmental work and approve the establishment of non-governmental environmental societies. The following is a suggested draft policy for the first non-governmental environmental society in the Kingdom of Saudi Arabia.

\section{CHARTER}

1. Name of the society:

Saudi Arabian Nature Association (SANA) or

Saudi Association of the Friends of the Environment (SAFE)

2. Location:

The City of Al-Riyadh. It can have branches in other cities.

3. Goals:

SANA or SAFE aims to accomplish the following:

a. Participate in the implementation of the goals of the National Development Plans as encouraged by the Saudi government's policies, Islamic teachings and the United Nations conference on environment and development kriown as the Earth Summit.

b. Increase environmental awareness among the people of Saudi Arabia, the region and the rest of the world.

c. Conduct environmental studies and research to solve local, national and global environmental problems.

d. Provide a forum for communication between members, raise their scientific and professional performance and foster better national 
and international coordination on environmental affairs.

e. Provide information and scientific consultation and advice both to government and the public.

f. Communicate and cooperate with other non-governmental societies in Saudi Arabia and outside.

4. Activitios:

The society can accomplish its above-stated goals by all feasible means, and can specifically do the following:

a. Conduct environmental studies, research and surveys, and publish, distribute and exchange results with concerned bodies.

b. Organize and hold seminars, symposia and conventions to discuss and solve environmental problems and issues.

c. Publish a periodical environmental magazine or newsletter concerned with environmental news, research and other environmental affairs.

d. Conduct environmental education and awareness projects, sponsor contests and any other activity that leads to a better public understanding of the environment.

e. Establish a permanent environmental resource center.

5. Membership:

Membership is of three types:

a. Honorary membership.

b. Working membership for environmental specialists and those who can participate in, any of the activities.

c. Guardian or Sponsor membership for those who wish to support the society and its activities with contributions only.

6. Conditions of membership:

a. Pay the membership fees decided by the society.

b. Submit an application endorsed by two working members. 
c. Approval of application by the trustee board.

7. Administration:

The society is administered by three bodies:

a. The trustee board, which is comprised of seven members including the secretary general.

b. The general assembly, which is composed of working members.

c. The secretary and the support staff rianage the daily affairs of the society and supervise the environmental resource center.

d. The ad hoc and permanent committees.

The rules and procedures of these bodies shall conform to the guidelines set forth by the Saudi Arabian Government, such as the philanthropic societies poiicy issued by the Ministry of Labor and/or the disciplinary societies policy issued by the Ministry of Higher

Education.

8. The Honorary President:

The Honorary President of the society is H.R.H. the Minister of Defence and Aviation, the Inspector General, and Chairman of the Ministerial Commission for the Environment.

9. Financial Resources:

The financial resources of the society come from the following:

a. Membership fees.

b. Contributions, gifts and zakat (charity tax).

c. Activities and publications revenues.

d. Governmental assistance. 
e. Inheritance wills and religious waqf "endowments."

f. Investment returns.

10. Financial Review:

A certified public accountant reviews the annual budget and expenditures of the society and follows procedures set by the philanthropic societies policy.

SANA or SAFE can complement the efforts of the Saudi Arabian environmental organizations in protecting the erivironment through education, research and coordination of environmental affairs. 


\section{REFEPENCES}

A major reference for this thesis is the Holy Koran.

AbdalBaqi, M.F. (1980). Indexed Reference of the Words of the Holy Kor'an. Cairo: Islamic Library.

AbdAllah, A. (1985). Report on the Environmental Management in the States of the Western Region of Asia. Bahrain: UNEP.

Abulkhair, Yahya et al. (Eds.). (1989). Proceeding of the Workshop on Desert Studies in the Kingdom of Saudi Arabia: Scopes and Concerns. AlRiyadh, Saudi Arabia: King Saud University Press.

Al-Bogomi, T. (1994). Practical Applications of Al-husbah in the Kingdom of Saudi Arabia from 1351-1408 A.H. Al-Riyadh, Saudi Arabia: AlFarazdaq.

Al-Farraj, M. M. (1990). Terrestrial Ecosystems: The Status and Trends, with Special Reference to Saudi Arabian Natural Vegetation. Proceedings of Workshop I on the Ecological Imperatives for Sustainable Development in the Kingdom of Saudi Arabia. Al-Riyadh, Saudi Arabia: NCWCD.

Al-Gain, A.A. (1989). Principles of a National Strategy for the Conservation of the Environment of the Kingdom of Saudi Arabia. In A. Abu-Zinada, P. Goriup \& I. Nader (Eds.), Proceedings of the First Symposium on Wildlife Conservation and Development in Saudi Arabia (pp. 18-26). Al-Riyadh, Saudi Arabia: NCWCD.

Al-Garny, A.H. (1994). Al-husbah in the Past and Present: Maintaining the Goals and Developing the Approach. (2 vols.) Al-Riyadh, Saudi Arabia: Al-Rushd.

Al-Hakamy, A. (1989). Deyelopment Plans and Their Role in Environment Protection and Wildlife Conservation and Development in Saudi Arabia. In A. Abu-Zinada, P. Goriup \& I. Nader (Eds.), Proceedings of the First Symposium on Wildife Conservation and Development in Saudi Arabia (pp. 1-9). Al-Riyadh, Saudi Arabia: NCWCD.

Al-Hogail, S. (1992). Propagating Virtue and Forbidding Vice: In Light of the Book of Allah and the Sunnah of His Messenger. Al-Riyadh, Saudi Arabia: Al-Farazdaq. 
Al-Mawdudi, A. (1978). First Principles of the Islamic State. (5th ed.). Lahore, Pakistan: islamic Publications.

Al-Mawdudi, A. (1980). Human Rights in Islam. (2nd ad.). London: Islamic Foundation.

Ai-Motairy, O. (1994, February 7). National register to hunt tumors. Okaz. (Saudi Arabia), p. 40.

Al-Nahdha Philanthropic Society for Women. (1993). The Thirty First Annual Report. Al-Fiyadh, Saudi Arabia: Al-Raja.

Al-Qunaibet, M. (1994). Agriculture and Water: The Status Quo and the Future. Proceedings of the Eighth Annual Meeting of the Saudi Economy Society. Al-Riyadh, Saudi Arabia: King Saud University.

Al-Rawaf, O. (1980). The Concept of the Five Crises in Political Development-Relevance to the Kingdom of Saudi Arabia. Unpublished docioral dissertation, Duke University.

Al-Saflan, A.M. (1981). The Essence of Tribal Leaders' Participation, Responsibilities and Decisions in Soine Local Government Activities in Saudi Arabia: A Case Siudy of the Ghamid and Zahran Tribes. Unpublished doctoral dissertation, Claremont Graduate School

Al-Senany, A.A. (1981). Effects of the Federal Clean Air Act on Santa Clara County, California. Senior thesis, San Jose State University.

Al-Shebaiky, A. (1992). Women's Volunteer Effoits in Social Care in the Kingdom of Saudi Arabia: A Study in Their Origins, Mandates, Accomplishments. Unpublished Mastor's thesis, King Saud University, Al-Riyadh, Saudi Arabia.

Al-Sudairy, T. (1993, September 3). Constitutional Policy in the Kingdom of Saudi Arabia. Al-Riyadh (Saudi Arabia) p. 7.

Al-Tabari, I. (1953). Jami" Al-Eayan. Cairo: Dar Al-ma'arif.

Al-Welaie, A. N. (1989). Factors Contributing to the Degredation of the Environment in Ceritral, Eastern and Northern Saudi Arabia. In A. Abu-Zinada, P. Goriup \& I. Nader (Eds.), Proceedings of the First Symposium on Wildlife Conservation and Development in Saudi Arabia (pp. 37-61). Al-Riyadh, Saudi Arabia: NCWCD.

Al-Welaie, A. N. (1994). Environmental Determinism and the Management of Environmental Resources in Arid Lands. Proceedings of the Fifth Geographical Conference of Geography Departments in Saudi Arabian Universities. Al-Riyadh, Saudi Arabia: King Saud 
University Press.

Al-Zelfah, M. (1994, June 18). Environmental Protection: A Cultural Imperative. Al-Riyadh (Saudi Arabia) p. 7.

Amer, M.H. (1985). Epidemiologic Aspects of Esophageal Cancer in Saudi Arabian Patients. Al-Riyadh, Saudi Arabia: The King Faisal Specialist Hospital Medical Journal, 5, 2.

Arif, M. (1994, March 5). Report on philanthropic volunteer work in Saudi Arabia. Al-Riyadh, (Saudi Arabia) p. 11.

Asad, M. (1980). The Principles of State and Government in Islam. (2nd ed.). Gibraltar, Britain: Dar Al Andalus.

Bakhashab, O.A. (1990). Islamic Law and the Environment: Some Basic Principles. In A. H. Dahlan (Ed.), Politics, Administration \& Development in Saudi Arabia. Brentwood, MD: Amana.

Barnard, C.I. (1947). The Functions of the Executive. (6th ed.). Cambridge: Harvard University Press.

Bradiey, Mi.D. (1973). Decision Niaking for Environmentai Resources Mianagement. Journal of Environmental Management, 1, 289-302.

Bucaille, M. (1989). The Bible, The Qur'an and Science. Paris: Seghers.

Burhenne, W. (1989). Legal Aspects of Wildlife Conservation in Saudi Arabia. In A. Abu-Zinada, P. Goriup \& !. Nader (Eds.), Proceedings of the First Symposium on Wiidlife Conservation and Development in Saudi Arabia, pp. 72-76. Al-Riyadh, Saudi Arabia: NCWCD.

Council of Ministers, Experts Branch (1408 H). Charter of the National Commission for Wildlife Conservation and Development. Al-Riyadh, Saudi Arabia: Author.

Dahlan, A.H. (1984). A Study of the Internal Political System of the Kingdom of Saudi Arabia. Jeddah, Saudi Arabia: Dar Al-Shoroog.

Dahlan, A.H. (Ed.) (1990). Politics, Administration \& Development in Saudi Arabia. Brentwood, MD: Amana.

Draz, O. (1985). The Hema System of Range Reserves in the Arabian Peninsula: Its Possibilities in Range Improvement and Conservation Projects in the Neart East. In J. A. McNeely \& D. Pitt (Eds.), Culture And Conservation: The Human Dimension in Environmental Planning. (pp. 109-121). London: Croom Helm.

El-Sharif, A.S. (1994). The Geography of the Kingdom of Saudi Arabia. (2 
vols.) (4th ed.) Al-Riyadh, Saudi Arabia: Al-Mareekh.

Friedl, J. (1976). Cultural Anthropology. New York: Harper's College Press.

Garlauskas, A. B. (1975). Conceptual Framework of Environmental Management. Joumal of Environmental Management, 3, 185-203.

Greenpeace says coastline took beating. (1991, September 5). Arab News, (London), p. 2.

Gulf Scientists downplay oil-well fire damage. (1991, September 5). Arab News, (London), p. 2.

Gulick, L. (1987). Notes on the Theory of Organization. In J. Shafritz \& A. Hyde (Eds.), Classics of Public Administration (pp.79-89). Chicago: The Dorsey Press.

Henning, D. H. \& Mangun, W. R. (1989). Managing the Environmental Crisis. Durham: Duke University Press.

Ibn Kathir. (1993). The Interpretation of the Holy Koran. (4 vols.) Beirut: Cultural Books.

Ibn Khaldun. (1967). The Mugaddimah: An Introduction to History. (2nd ed.) Frank Rosenthal (Tr.). Princeton, N.J.: Princeton University Press.

Ibn Taymiyyah, A. (1988). Majmoo' Al-Fatawa. (37 vols.) Al-Riyadh, Saudi Arabia: Al-Salam.

Ibn Taymiyyah, A. (n.d.) Al-husbah in Islam. Al-Riyadh, Saudi Arabia: Al-Fikr.

Jordan, W. J. \& Rowntree, L. (1986). The Human Mosaic: A Thematic Introduction to Cultural Geography (4th ed.) Cambridge, MA: Harper \& Row.

Katz, D. \& Kahn, R. (1987). Organizations and the Systems Concept. In J. Shafritz \& A. Hyde (Eds.), Classics of Public Administration (pp.286-298). Chicago: The Dorsey Press.

Lipsky, G. (1959). Saudi Arabia: Its People, Iis Society, Its Culture. New Haven, CT: HRAF Press.

Matthews, W. H. \& Perkowski, J. C. (1975). Integrating Scientific Knowledge for Professional Education in Environmental Management. Environmental Conservation, 2, 213-22.

(MEPA) Meteorology and Environmental Protection Administration. (1982). Environmental Protection Standards in the Kingdom of Saudi Arabia, 
Document No. 1401-01. Jeddah, Saudi Arabia: Author.

(MEPA) Meteorology and Environmental Protection Administration. (1989). The State of the Environment in the Kingdom of Saudi Arabia, (2 vols.) Jeddah, Saudi Arabia: MEPA.

(MEPA) Meteorology and Environmental Protection Administration. (1983, 1993). Basic Paper On The Islamic Principles for the Conservation of the Natural Environment. Jeddah, Saudi Arabia: MEPA \& IUCN.

Milbrath, L.W. (1984). Environmentalists: Vanguards for a New Society. Albany: State University of New York Press.

(MCE) Ministerial Commission for the Environnment. (1992). National Report to the United Nations Conference on Environment and Development. Al-Riyadh, Saudi Arabia: Ministry of Planning Press.

(MOLSA) Ministry of Labor and Social Affairs. (1990). A Collection of the Policies and Implementation Procedures of the Deputy Ministry for Social Care (3rd ed.). Al-Riyadh, Saudi Arabia: Al-Khalid.

(MOLSA) Ministry of Labor and Social Affairs. (in.d.) Policies of Fhilanthropic Societies and Foundations. Al-Diri'yah, Saudi Arabia: Training and Social Research Center Press.

(MOP) Ministry of Planning. (1989). Fifth Development Plan, 1410-1415 A.H./1990-1995 A.D. Al-Riyadh, Saudi Arabia: Ministry of Planning Press.

(MOP) Ministry of Planning. (1993). General Objectives and Strategic Bases of the Sixth Development Plan, 1415-1420 A./1995-2000 A.D. AlRiyadh, Saudi Arabia: Ministry of Planning Press.

Mohammadain, M.M. (1994). Environmental Security in our Islamic Heritage. Proceedings of the Fifth Conference of Geography Departments in Saudi Universities. Al-Riyadh, Saudi Arabia: King Saud University Press.

Nader, I. A. (1990). General Status of the Terrestrial Vertebrate Fauna of Saudi Arabia. Proceedings of Workshop I on the Ecological Imperatives for Sustainable Development in the Kingdom of Saudi Arabia. Al-Riyadh, Saudi Arabia: NCWCD.

Nash, R.F. (1989). The Rights of Nature: A History of Environmental Ethics. Madison: The University of Wisconsin Press.

Nasser, S. (1976). The Importance of Community Development in the Development of the Southwest Region of Saudi Arabia. Unpublished doctoral dissertation, Michigan State University. 
National Commission for Wildlife Conservation and Development, Annual Reports. (1987-1993). Al-Riyadh, Saudi Arabia: NCWCD.

O'Riordan, T. (1982). Institutions Affecting Environmental Policy. In Institutions and Geographical Patterns. R. Flowerdew (Ed.), pp. 103-140. London: Croom Helm.

Park, C.C. (Ed.) (1986). Environmental Policies: An International Review. London: Croom Helm.

Qutb, S. (1977). Islam and Universal Peace. Indianapolis: American Trust Publications.

Sa'aty, A. (1985). Public Administration in Saudi Arabia. Jeddah, Saudi Arabia: Al-Shoroog.

Saleh, A. (1984). All Kinds of Things in Due Balance. Jeddah, Saudi Arabia: Okaz Press.

(SSCC) Saleh Bin Saleh Cultural Center. (1993). Features of the Social Work in Unayzah. Unayzah, Saudi Arabia: National Press.

Samarrai, M. I. (n.d.). Environmental Protection and Islam. Jeddah, Saudi Arabia: King Abdal-Aziz University

Senany, A. M. (1990). Development Planning: Public Functions and Private Sector Participation in the Kingdom of Saudi Arabia. Unpublished doctoral dissertation, Florida State University, Tallahassee.

Shakun, M. F. (1981). Policy making and meaning as design of purposeful systems. International Journal of General Systems, 7. 235-51.

Shamekh, A. A. (1977). Bedouin settlements. Ekistics, 258. 249-260.

Simon, H. (1987). The Proverbs of Administration. In J. Shafritz \& A. Hyde (Eds.), Classics of Public Administration (pp. 164-180). Chicago: The Dorsey Press.

Soliman, S. (1992). Pesticide Use in the Kingdom of Saudi Arabia and its Effects on Man and the Environment. Proceedings of the Convention on Environment and Development: Complementation, Not Confrontation. Al-Riyadh, Saudi Arabia: Gulf Cooperation Council Secretariat General.

Soliman, S., Waters, M., Ahmed, N. \& Askar, A. (1992). Genetic Bioassays of Selected Pesticides with Emphasis on Compounds Used in Saudi Arabia. Unpublished manuscript. 
(SRI) Stanford Research Institute. (1984). The State of the Environment: Kingdom of Saudi Arabia. SRI Project No. 4559. Menlo Park, CA: SRI Press (Unpublished).

Starke, L. (1990). Signs of Hope: Working Towards Our Common Future. Oxford: Oxford University Press.

Steward, J. H. (1955). Theory of Culture Change: the Methodology of Multilinear Evolution. Urbana: University of Illinois Press.

Toffler, A. (1970). Future Shock. New York: Bantam Books.

United Nations. (1992). United Nations Conference on Environment and Development: Agenda 21, Vol. 3, Chapter 27 (pp. 19-22). Rio De Janeiro: Author.

(UNEP/ROWA) Inited Nations Environment Program/Regional Office for West Asia. (1992, March). Newsletter, 5, 10. Bahrain: Author.

Verba, S., et al. (1978). Paricicipation and Political Equality: A Seven Nation Comparison. Chicago, IL: The University of Chicago Press.

Waldo, D. (1955). The Study of Public Administration. New York: Random House.

Weiner, M. (1971). Political Participation: Crisis of the Political Process. In Leonard Bender, et al. (Eds). Crises and Sequences in Political Development. Princeton, NJ: Princeton University Press.

Wengert, N. (January, 1976). Citizen Participation: Practice in Search of a Theory. Natural Resources Journal, 16.

White, L., Jr. (March 10, 1967). The historical roots of our ecologic crisis. Science, 155, 1203-1207.

Wilcox, D. \& Ault, P. \& Agee, K. (1992). Public Relations: Strategies and Tactics. (3rd ed.) New York: Harper Collins.

Wittmer, W. \& Buttiker, W. (Eds.) (1979). Fauna of Saudi Arabia. (11 vols.) Basle, Switzerland: Pro Entmologia.

World Resources Institute. (1990). World Resources 1990-91: A Guide to the Global Environment. New York: Oxford University Press. 